\title{
De rechten van verdediging van de rechtspersoon in de Belgische strafprocedure: van verre evident, maar verre van evident
}

\author{
Filiep Deruyck ${ }^{*}$
}

\section{Inleiding}

I. De aanvaarding dat naast fysieke personen ook rechtspersonen strafrechtelijk verantwoordelijk moeten kunnen worden gesteld, is er niet zonder slag of stoot gekomen.

De volgende passage uit de plenaire bespreking van het Franse wetsontwerp strekkende tot de invoering van een nieuwe Code pénal - waarin de strafrechtelijke verantwoordelijkheid van de rechtspersoon werd opgenomen ${ }^{\mathrm{I}}$ - illustreert dit in rake bewoordingen: ${ }^{2}$

M. Michel Sapin, président de la Commission: L'objet des dispositions que nous proposons à l'Assemblée, le principe de la responsabilité [pénale] des personnes morales, est précisément de faire en sorte que les victimes aient le droit à la reconnaissance par la société d'une responsabilité pénale, que l'on ne désigne pas comme responsable quelqu'un qui ne fait que porter le chapeau, mais que l'on trouve le vrai responsable.

M. Jacques Toubon: Qui est responsable?

M. Michel Sapin, président de la Commission: Cette proposition, monsieur Toubon, n'est pas sortie du chapeau ou de la tête en peu embrumée de tel ou tel juriste.

M. Jacques Toubon: Mais qui est le vrai responsable, monsieur Sapin?

M. Michel Sapin, président de la Commission: La personne morale, justement!

M. Jacques Toubon: Mais qui est-ce?

M. Michel Sapin, président de la Commission: Vraiment sur ce point, vous êtes en proie à un blocage intellectuel ...

M. Jacques Toubon: Allons, monsieur Sapin!

* Prof. dr. Filiep Deruyck is werkzaam bij de afdeling Strafrecht, vakgroep Publiekrecht aan de Vrije Universiteit Brussel en advocaat bij de balie te Antwerpen.

I Meer bepaald in artikel I2I-2 van de nieuwe Code pénal, goedgekeurd door vier wetten van 22 juli 1992 (wetten n ${ }^{\circ} 92-683,92-684,92-685$ en 92-686, Journal Officiel 23 juli 1992), in werking getreden op I maart I994.

2 Franse Parl. Hand., Assemblée Nationale, rière Session Ordinaire I989-9o, zitting van II oktober I989, p. 3410. 
M. Michel Sapin, président de la Commission: ou vous êtes victime de ce conservatisme profond - le mot n'étant pas pris dans son sens politique - que M. Marchand décrivait très bien tout à l'heure. Parce que vous ne la voyez pas écrite dans les livres anciens de droit, vous vous dites que telle notion n'existe pas. Et bien, modernisons le droit!

Welnu, het recht werd gemoderniseerd, niet alleen in Frankrijk ('Als het regent in Parijs ...') maar ook in België (' ... dan druppelt het in Brussel').

Inderdaad, door de wet van 4 mei 1999 werd de strafrechtelijke verantwoordelijkheid van de rechtspersoon ingevoerd in het Belgisch Strafwetboek, ${ }^{3}$ meer bepaald in artikel $5 \mathrm{Sw}$.

2. Tijdens de parlementaire voorbereiding werden twee belangrijke uitgangspunten, die trouwens onderling nauw met elkaar verbonden zijn, meermaals benadrukt.

Vooreerst werd er op gewezen dat wordt geopteerd voor een autonoom stelsel van strafrechtelijke verantwoordelijkheid van rechtspersonen, dus uitdrukkelijk niet voor een stelsel waarbij de strafrechtelijke verantwoordelijkheid van de rechtspersoon wordt afgeleid van de eigen strafrechtelijke verantwoordelijkheid van deze of gene natuurlijke persoon of personen. Het is van belang te onderstrepen:

'dat de opstellers van dit voorstel uitgaan van de rechtspersoon als maatschappelijke realiteit die een eigen strafrechtelijke fout kan begaan en hier dan ook op strafrechtelijk vlak voor aansprakelijk moet kunnen worden gesteld.'4

Het tweede uitgangspunt is het logisch gevolg van het vorige: in dat autonoom stelsel van strafrechtelijke verantwoordelijkheid wordt gestreefd naar een zo groot mogelijke gelijkschakeling van de rechtspersonen met de natuurlijke personen. Reeds bij het prille begin van de toelichting bij het wetsvoorstel luidt het:

'De basisfilosofie hierbij is dat in de mate van het mogelijke rechtspersonen worden geassimileerd met natuurlijke personen. ${ }^{5}$

3 Wet van 4 mei 1999 tot invoering van de strafrechtelijke verantwoordelijkheid van rechtspersonen, Belgisch Staatsblad (hierna BS), 22 juni I999. Bij gebreke aan andersluidende bepaling trad deze wet in werking de tiende dag na de publicatie ervan, meer bepaald op 2 juli 1999.

De totstandkoming van deze wet verliep volgens een wat eigenaardig parcours. Binnen de regering werd een voorontwerp van wet opgesteld, dat voor advies werd voorgelegd aan de Raad van State. $\mathrm{Na}$ de opmerkingen van de Raad te hebben ontvangen, werd een 'verbeterde' tekst in de Senaat ingediend, niet als wetsontwerp, maar als wetsvoorstel ondertekend door H. VANDENBERGHE, R. LALLEMAND en F. ERDMAN (zie de inleidende uiteenzetting door de indieners van het wetsvoorstel in de Senaatscommissie voor Justitie, Parl. St., Senaat, I998-99, nr. I-I217/6, p. 5).

Het oorspronkelijke voorontwerp van wet werd dus nooit ingediend. Het advies van de Raad van State bij dat voorontwerp werd wel opgenomen als bijlage bij het verslag namens de Senaatscommissie voor Justitie (Parl. St., Senaat, I998-99, nr. I-I2I7/6, p. II4 e.v.).

4 Toelichting bij het wetsvoorstel, Parl. St., Senaat, I998-99, nr. I-I2I7/I, p. 2.

5 Toelichting bij het wetsvoorstel, Parl. St., Senaat, I998-99, nr. I-I2I7/I, p I. Dezelfde wens tot 'assimilatie' van de rechtspersonen met de natuurlijke personen stond al in de memorie van toelichting bij het voorontwerp van wet, zoals geciteerd in het advies van de Raad van State (Parl. St., Senaat, I998-99, nr. I-I2I7/6, p. II7). 
De link tussen beide uitgangspunten wordt overigens ook door de wetgever klaar en duidelijk gelegd:

'De rechtspersoon kan een fout begaan, laakbaar gedrag vertonen en gestraft worden, zonder dat de natuurlijke personen geïdentificeerd hoeven te worden: hun verantwoordelijkheid wordt gedragen door de rechtspersoon. In die zin wordt de rechtspersoon gelijkgesteld met een natuurlijke persoon. ${ }^{6}$

Kortom: de rechtspersoon kan strafrechtelijk vervolgd en veroordeeld worden op basis van eigen daderschap en op basis van eigen schuld en verschilt daarin dus niet van de natuurlijke persoon. Dit wordt in de doctrine wel eens aangeduid met de term 'antropomorfisme'.

3. Dergelijke visie is van grote invloed geweest op tal van materieelrechtelijke vraagstukken. In zijn inleidende uiteenzetting voor de Kamercommissie voor Justitie benadrukte de minister van Justitie uitdrukkelijk:

'Op het vlak van de algemeen geldende strafrechtelijke beginselen, werd de gelijkstelling van de rechtspersonen met de natuurlijke personen zover mogelijk doorgedreven."

Zo hangt de vervolging van een rechtspersoon niet af van die van een natuurlijke persoon, noch omgekeerd: artikel $5 \mathrm{Sw}$. doet immers geen afbreuk aan de gewone regels van toerekening van een misdrijf aan de daders of mededaders ervan. ${ }^{9}$

Het staat tevens vast dat de hoedanigheid van de natuurlijke persoon die het misdrijf in de feiten heeft verwerkelijkt, er niet toe doet: het hoeft dus niet te gaan om een orgaan of wettelijk vertegenwoordiger van de rechtspersoon, ${ }^{\text {10 }}$ maar kan ook gaan om een aangestelde of werknemer, zelfs om een persoon van buiten de rechtspersoon (zoals bv. een zelfstandige boekhouder of een persoon binnen een extern sociaal secretariaat). De materiële gedraging kan dus door gelijk wie worden gesteld.

De vraag, wie de materiële gedraging heeft gesteld, is a.h.w. een valse vraag. De juiste vraag is, wanneer een materiële gedraging geacht kan worden door een rechtspersoon te zijn gepleegd. Wat dat handelen betreft heeft de Belgische wetgever ervoor geopteerd wettelijke criteria te ontwikkelen, die bepalend zijn voor de vraag of een welbepaald handelen (of nalaten) door een natuurlijke persoon kan worden beschouwd als handelen (of nalaten) door de rechtspersoon.

6 Verslag namens de Senaatscommissie voor Justitie, Parl. St., Senaat, I998-99, nr. I-I2I7/6, p. I8. Vergelijk met het verslag namens de Kamercommissie voor Justitie, Parl. St., Kamer, I998-99, nr. $2093 / 5$, p. 3 .

7 S. COISNE en P. WAETERINCKX, 'La sauvegarde des droits de la défense d'une personne morale, son droit au silence et le mandataire ad hoc comme garant de ces droits', in La responsabilité pénale des personnes morales en Belgique, M. NIHOUL (ed.), Brussel, La Charte, 2005, 312.

8 Verslag namens de Kamercommissie voor Justitie, Parl. St., Kamer, I998-99, nr. 2093/5, p. 3.

9 Cass. I2 september 2006, AR P.o6.0598.N.

Io Zoals dat wel het geval is in de Franse regeling. Artikel I2I-2, Ite lid van de Franse Code pénal luidt inderdaad als volgt: 'Les personnes morales, à l'exclusion de l'Etat, sont responsables pénalement, selon les distinctions des articles 121-4 à 121-7, des infractions commises, pour leur compte, par leurs organes ou représentants' (eigen benadrukking). 
Die criteria - waar het in dit preadvies verder niet over hoeft te gaan - zijn drieledig: een handeling (of onthouding) wordt geacht door een rechtspersoon te zijn gepleegd, indien zij ofwel een intrinsiek verband heeft met de verwezenlijking van zijn doel, ofwel een intrinsiek verband heeft met de waarneming van zijn belangen, ofwel, naar blijkt uit de concrete omstandigheden, voor zijn rekening is gepleegd (art. 5, I $^{\text {ste }}$ lid Sw.).

Voorts staat vast dat het moreel bestanddeel moet beoordeeld worden in hoofde van de rechtspersoon. Recent herhaalde het Hof van Cassatie het reeds eerder ${ }^{\text {II }}$ geformuleerde principiële standpunt, dat voor het vaststellen van de strafrechtelijke verantwoordelijkheid van de rechtspersoon niet volstaat dat de rechter zou vaststellen dat de natuurlijke persoon de fout wetens en willens heeft gepleegd, maar dat hij ook bij de rechtspersoon de fout moet vaststellen en deze pas vaststaat, indien de verwezenlijking van het misdrijf hetzij volgt uit een wetens en willens genomen beslissing binnen de rechtspersoon, hetzij het gevolg is van een binnen deze rechtspersoon gepleegde nalatigheid. ${ }^{12}$

De wetgever heeft hier - begrijpelijkerwijze - geen criteria ontwikkeld om aan te duiden wanneer de rechtspersoon geacht wordt schuldig (met het vereiste moreel bestanddeel, dus met opzet of uit onachtzaamheid) te hebben gehandeld. Dat is, overigens zoals bij natuurlijke personen, een feitenkwestie die door de rechter zal moeten worden beoordeeld. ${ }^{13}$ Dat in die zoektocht naar het moreel bestanddeel van de rechtspersoon vooral wordt gekeken naar de organen of wettelijke vertegenwoordigers, ${ }^{14}$ is nogal wiedes, maar men mag zich daar niet toe beperken. ${ }^{15}$

Zelfs bij de bepaling van de straffen voor rechtspersonen werd de gelijkstelling met de natuurlijke personen zo veel mogelijk doorgetrokken. De wetgever heeft een zo groot mogelijk parallellisme tot stand willen brengen met de straffen, die voor dezelfde misdrijven kunnen worden opgelegd aan natuurlijke personen. ${ }^{\mathrm{I}}{ }^{\mathrm{N}} \mathrm{Nu}$ voor natuurlijke personen de hoofdstraf meestal een vrijheidsstraf is, die uit haar aard niet voor rechtspersonen in aanmerking komt, is de hoofdstraf voor rechtspersonen integendeel de geldboete, waarvan de hoogte dan wel in verhouding moet staan met de vrijheidsstraf van de natuurlijke persoon. Daartoe werd, in artikel 4Ibis Sw., een conversiemechanisme ingevoerd, waarbij het aantal maanden van de vrijheidsstraf voor de natuurlijke persoon wordt vermenigvuldigd met een bepaalde

II Zie Cass. I2 juni 2007, AR P.07.0246.N en Cass. 23 september 2008, AR P.o8.587.N.

I2 Cass. 30 april 20I3, AR P.I2.I290.N.

I3 Zie over de netelige kwestie van het moreel bestanddeel van de rechtspersoon verder F. DERUYCK, 'Hoe eigen(aardig) is de strafrechtelijke verantwoordelijkheid van de rechtspersoon?', in Amicus Curiae. Liber Amicorum Marc De Swaef, Antwerpen-Cambridge, Intersentia, 2013, I29 e.v., i.h.b. I33 e.v.

I4 Zie bv. Cass. 20 april 20II, AR P.ro.2026.F: 'Als het strafbaar feit door een vennootschap is gepleegd, is het opzet genoegzaam bewezen door de vaststelling dat de leidinggevende organen kennis hadden van het opzet om de schuldige handeling te stellen en daarmee hebben ingestemd.'

I5 Zo uitdrukkelijk de minister van Justitie tijdens de behandeling van het wetsvoorstel in de Senaatscommissie voor Justitie, Parl. St., Senaat, I998-99, nr. I-I2I7/6, p. 20.

I6 Toelichting bij het wetsvoorstel, Parl. St., Senaat, I998-99, nr. I-I2I7/I, p. 7. 
multiplicator, ${ }^{17}$ om zo tot een overeenstemmende geldboete voor de rechtspersoon te komen. Gaat het om een levenslange vrijheidsstraf, dan heeft de wetgever rekening gehouden met het feit dat de levenslang gestrafte niettemin op een bepaald ogenblik voorwaardelijk in vrijheid wordt gesteld: de periode van de effectieve vrijheidsberoving wordt bij levenslang gestraften - enigszins met de natte vinger - geschat tussen 20 tot 60 jaar (of 240 tot 720 maanden), ${ }^{18}$ hetgeen dan ${ }^{19}$ heeft geleid tot een geldboete voor de rechtspersoon van 240.000 tot 720.000 euro ...

4. Het is evenwel opmerkelijk te moeten vaststellen dat de ijver waarmee de rechtspersoon op het materieelrechtelijk vlak wordt gelijkgeschakeld met een natuurlijk persoon - eigen daderschap, eigen schuld, dus eigen strafrechtelijke verantwoordelijkheid met overeenstemmende straffen - niet wordt doorgetrokken naar het formeelrechtelijk vlak. De rechtspersoon die riskeert strafrechtelijk verantwoordelijk te worden gesteld en bijgevolg te worden veroordeeld, dient immers tijdens de strafprocedure - die in die veroordeling zou kunnen uitmonden - dezelfde rechten van verdediging te kunnen uitoefenen als de natuurlijke persoon.

Hierover - dus over de rechten van verdediging van de rechtspersoon - is in de parlementaire voorbereiding van de wet van 4 mei 1999 niets - werkelijk geen letter terug te vinden. Dat kan enkel en alleen verklaard worden door het feit dat de wetgever het vanzelfsprekend vond, dat ook de rechtspersoon die strafrechtelijk vervolgd wordt over de rechten van verdediging beschikt: Van ver evident ...

Doch in de praktijk dient vastgesteld te worden dat bepaalde fundamentele rechten van verdediging in hoofde van de rechtspersoon een wel heel eigenaardige invulling hebben gekregen: Verre van evident ...

Eén en ander heeft, naar Belgisch recht, vooral te maken met de wettelijke regeling betreffende de vertegenwoordiging (en daarmee samenhangend de verschijning) van de rechtspersoon en het gebrek aan wettelijke regeling m.b.t. de invulling van het zwijgrecht van de rechtspersoon.

Hierna wordt op deze beide kwesties dieper ingegaan. De bespreking ervan vormt het leeuwendeel van dit preadvies.

Daarna wordt, in de mate van het mogelijke en ten behoeve van de rechtsvergelijking, nog kort ingegaan op de positie van de rechtspersoon bij enkele daden van onderzoek, die vanuit de Nederlandse rechtspraktijk als problematisch worden ervaren en om die reden in het Nederlandse preadvies mede aan bod zijn gekomen.

I7 Meer bepaald 500 te vermenigvuldigen met het aantal maanden van de minimumstraf, 2000 te vermenigvuldigen met het aantal maanden van de maximumstraf (art. 4I I bis, $\S \mathrm{I}, 2^{\text {de }}$ lid, $2^{\text {de }}$ streepje Sw.).

I8 Toelichting bij het wetsvoorstel, Parl. St., Senaat, I998-99, nr. I-I2I7/I, p. 8.

I9 Dit keer blijkbaar te vermenigvuldigen met een multiplicator Iooo ... 


\section{De vertegenwoordiging en de verschijning van de rechtspersoon}

5. Tijdens de parlementaire voorbereiding werd meermaals benadrukt dat de regeling van de vertegenwoordiging van de rechtspersoon (artikel 2 bis V.T.Sv. ${ }^{20}$ ) en die van de verschijning van de rechtspersoon (art. 152 en I85 Sv. ${ }^{21}$ ) goed uit elkaar gehouden moeten worden. ${ }^{22}$

Dat is in die zin juist, dat de rechtspersoon niet altijd dient vertegenwoordigd te worden in de zin van artikel 2bis V.T.Sv., maar in principe - behoudens verstek wel altijd dient te verschijnen voor de strafrechter. Doch dat verschijnen van de rechtspersoon gebeurt hoe dan ook via een vertegenwoordiger, onder omstandigheden trouwens dezelfde vertegenwoordiger als degene die met toepassing van artikel 2bis V.T.Sv. werd aangeduid (zie hierna, nr. 32).

\section{I.I De vertegenwoordiging van de rechtspersoon overeenkomstig artikel 2 bis V.T.Sv.}

6. Met artikel 2bis V.T.Sv. beoogde de wetgever een regeling in te voeren ter oplossing van een mogelijk belangenconflict tussen de rechtspersoon en een orgaan of wettelijk vertegenwoordiger, welk conflict optreedt wanneer het orgaan of die wettelijk vertegenwoordiger ook wordt vervolgd wegens dezelfde feiten als deze, waarvoor de rechtspersoon wordt vervolgd. ${ }^{23}$

Hoewel de wetgever dat belangenconflict verder niet nader heeft verduidelijkt of toegelicht, gaat het er ongetwijfeld om te vermijden dat de natuurlijke persoon, als vertegenwoordiger van de verdachte rechtspersoon, voor die rechtspersoon nadelige verklaringen aflegt of een voor die rechtspersoon nadelige processtrategie volgt, waarbij hij wel zijn eigen belangen als verdachte tracht te dienen.

Dat artikel 2bis V.T.Sv. luidt in zijn uiteindelijke vorm als volgt:

'Ingeval de strafvordering tegen een rechtspersoon en tegen degene die bevoegd is om de rechtspersoon te vertegenwoordigen, wordt ingesteld wegens dezelfde of samenhangende feiten, wijst de rechtbank die bevoegd is om kennis te nemen van de strafuordering tegen de rechtspersoon, ambtshalve of op verzoekschrift, een lasthebber ad hoc aan om deze te vertegenwoordigen.'

20 Door de wet van I7 april I878 (BS 25 april I878) werden de artikelen I t/m 7 van het Wetboek van Strafvordering (zie volgende voetnoot) impliciet opgeheven en vervangen door een Voorafgaande Titel van het Wetboek van Strafvordering, waarin de wetgever sindsdien tal van bepalingen 'dropt' die hij in het eigenlijke corpus van het Wetboek blijkbaar moeilijk weet te plaatsen.

2I Het (Napoleontisch) Wetboek van Strafvordering van 17 november I8o8 (Nederlandse tekst vastgesteld bij wet van ro juli i 967 , BS 6 september 1967 ).

22 Verslag namens de Senaatscommissie voor Justitie, Parl. St., Senaat, I998-99, nr. I-I2I7/6, p. 74: 'Er is dus wel degelijk een verschil tussen artikel 11 [tot invoering van artikel 2 bis V.T.Sv.] en het voorgestelde artikel 15 ter [tot wijziging van artikel ${ }^{8} 5 \mathrm{~Sv}$.]. Artikel 11 betreft de vertegenwoordiging bij belangenconflict, artikel 15 ter betreft de verschijning.'

23 Toelichting bij het wetsvoorstel, Parl. St., Senaat, I998-99, nr. I-I2I7/I, p. II; verslag namens de Senaatcommissie voor Justitie, Parl. St., Senaat, I998-99, nr. I-I2I7/6, p. 74. 
Met deze ene zin moet men het stellen. Wie meent dat door de studie van de parlementaire voorbereiding meer duidelijkheid wordt verschaft, is er aan voor de moeite: m.b.t. de lasthebber ad hoc is de parlementaire voorbereiding immers haast onbestaande. In de toelichting bij het wetsvoorstel wordt slechts één enkele paragraaf aan de lasthebber ad hoc gewijd, ${ }^{24}$ de neerslag van de bespreking ervan in de Senaatscommissie voor Justitie bedraagt amper anderhalve bladzijde ${ }^{25}$ en, wat de Kamercommissie voor Justitie betreft, amper een bladzijde. ${ }^{26}$ Tijdens de plenaire behandeling tenslotte passeerde de ontwerptekst van artikel 2 bis V.T.Sv. volkomen geruisloos, zowel in Kamer als in Senaat. ${ }^{27}$

7. Deze nagenoeg algehele radiostilte m.b.t. de lasthebber ad hoc tijdens de parlementaire voorbereiding - en waar die stilte dan al eens doorbroken wordt, doet het meestal pijn aan de oren (zie bv. hierna, nr. 8 en nr. I9) - kon absoluut niet doen vermoeden welke praktijkproblemen door de bondige regel van artikel 2 bis V.T.Sv. zouden ontstaan, welke rechtspraak er desbetreffend zou worden ontwikkeld en wat voor een karrevracht aan doctrine aan de figuur van de lasthebber ad hoc zou worden gewijd.

De regel van artikel 2 bis V.T.Sv. is ten gevolge van één en ander geweldig opgerekt: er worden tal van andere rechtsregels in gelezen die er helemaal niet instaan, maar die dan blijkbaar noodzakelijkerwijze uit deze bepaling zouden voortvloeien.

De hiernavolgende bespreking is dan ook geenszins uitputtend, maar is beperkt door het onderwerp van dit preadvies. De nadruk zal gelegd worden op de gevolgen van de aanduiding van een lasthebber ad hoc voor de uitoefening van de rechten van verdediging van de rechtspersoon, die hij geacht wordt te vertegenwoordigen.

In dat verband zijn m.i. vier vragen relevant: door wie wordt de lasthebber ad hoc aangesteld, wie wordt als lasthebber ad hoc aangesteld, is de aanstelling van de lasthebber ad hoc een automatisme telkens wanneer een rechtspersoon wordt vervolgd samen met een natuurlijke persoon die hem kan vertegenwoordigen, en tenslotte - en vooral - wat is het statuut, de taak, de bevoegdheid van de lasthebber ad hoc?

\section{I.I.I Door wie wordt de lasthebber ad hoc aangesteld?}

8. Volgens de letterlijke tekst van artikel 2bis V.T.Sv. dient de lasthebber ad hoc te worden aangewezen door 'de rechtbank die bevoegd is om kennis te nemen van de strafvordering tegen de rechtspersoon'. ${ }^{28}$ Dat is m.a.w. de feitenrechter, in de

24 Toelichting bij het wetsvoorstel, Parl. St., Senaat, I998-99, nr. I-I2I7/I, p. II.

25 Verslag namens de Senaatscommissie voor Justitie, Parl. St., Senaat, I998-99, nr. I-I2I7/6, p. 74-75.

26 Verslag namens de Kamercommissie voor Justitie, Parl. St., Kamer, I998-99, nr. 2093/5, p. 37-38.

27 Parl. Hand., Senaat, I6 maart I999 en I8 maart I999; Parl. Hand., Kamer, 27 april en 28 april I999.

28 In de tekst, zoals hij was goedgekeurd in de Senaat en werd overgezonden aan de Kamer, was er overigens sprake van 'de bevoegde rechtbank voor de uitoefening van de strafvordering tegen de rechtspersoon’ (Parl. St., Senaat, I998-99, nr. I-I2I7/II, p. 5; Parl. St., Kamer, I998-99, nr. 2093/I, p. 5). In de Kamercommissie voor Justitie werd evenwel door een parlementslid terecht opgemerkt dat een rechtbank niet bevoegd is voor de uitoefening van de strafvordering (dat is immers de taak van het 
meeste gevallen de correctionele rechtbank, die ook over de rechtspersoon zal oordelen. In de praktijk gaan inderdaad vele feitenrechters voor wie de rechtspersoon verschijnt, over tot het aanstellen van een lasthebber ad hoc. Het past dit goed voor ogen te houden, vooral wanneer hierna zal blijken welk statuut en welke bevoegdheden de lasthebber ad hoc bezit.

Als de figuur van de lasthebber ad hoc evenwel bestaat om een belangenconflict tussen rechtspersoon en natuurlijke persoon op te vangen, dan dringt de vaststelling zich op dat dergelijk belangenconflict reeds kan ontstaan - en in de praktijk ook vaak ontstaat - voorafgaand aan de vonnisfase. $\mathrm{Nu}$ de fase van het strafrechtelijk onderzoek bijzonder zwaar doorweegt op deze vonnisfase, lijkt het dan ook niet ondenkbaar dat er reeds tijdens de onderzoeksfase nood is aan het aanstellen van een lasthebber ad hoc.

Wanneer hier, terecht, door een lid van Kamercommissie voor Justitie op werd gewezen, antwoordde de vertegenwoordiger van de minister van Justitie:

'dat artikel 2bis niet uitsluit dat de bevoegde rechtbank reeds voor de terechtzitting (nl. tijdens het opsporings- of gerechtelijk onderzoek) een lasthebber ad hoc aanstelt mocht zulks noodzakelijk blijken.'29

En wanneer datzelfde parlementslid deze redenering doortrok en concludeerde dat, indien de strafvordering betrekking heeft op een misdaad die tijdens het onderzoek per definitie nog niet is gecorrectionaliseerd, de bevoegde rechtbank dan het hof van assisen is, werd dit door de vertegenwoordiger van de minister beaamd. ${ }^{30}$ Dergelijk standpunt komt er dus op neer dat de eerste voorzitter van het hof van beroep een hof van assisen zou moeten samenstellen, louter en alleen om een lasthebber ad hoc aan te stellen ...

9. Dat, in de mate de nood bestaat het mogelijk belangenconflict tussen rechtspersoon en natuurlijke persoon op te vangen door de aanduiding van een lasthebber ad hoc (zie desbetreffend hierna, nr. 30), dit dan ook tijdens het vooronderzoek mogelijk zou moeten zijn, kan bijgetreden worden.

Dat die lasthebber ook in dat geval zou moeten aangeduid worden door de rechtbank die bevoegd is om kennis te nemen van de strafvordering, is evenwel onaanvaardbaar om meerdere redenen.

Vooreerst kan de vertegenwoordiger van de minister van Justitie niet gevolgd worden wanneer hij voorhield, dat artikel 2bis V.T.Sv. niet zou beletten dat de rechtbank die bevoegd is om kennis te nemen van de strafvordering ook tijdens het opsporingsonderzoek een lasthebber ad hoc zou kunnen aanstellen. Artikel 2bis V.T.Sv. heeft het immers over het geval, waarin de strafvordering is ingesteld tegen een

openbaar ministerie), maar wel voor het kennis nemen van de strafvordering (en erover te oordelen: verslag namens de Kamercommissie voor Justitie, Parl. St., Kamer, I998-99, nr. 2093/5, p. 37).

29 Verslag namens de Kamercommissie voor Justitie, Parl. St., Kamer, I998-99, nr. 2093/5, p. 37.

30 Verslag namens de Kamercommissie voor Justitie, Parl. St., Kamer, I998-99, nr. 2093/5, p. 37-38. 
rechtspersoon en degene die bevoegd is om hem te vertegenwoordigen. Tijdens een opsporingsonderzoek is de strafvordering echter nog niet ingesteld. Dat zal maar gebeuren wanneer, op het einde van het opsporingsonderzoek, het openbaar ministerie overgaat tot dagvaarding en aldus de strafvordering instelt.

Op basis van de tekst van de wet zelf kan derhalve geen lasthebber ad hoc worden aangeduid in het kader van een opsporingsonderzoek. Als men er van uitgaat dat ook tijdens het opsporingsonderzoek - toch het overgrote deel van de vooronderzoeken in strafzaken - de noodzaak kan ontstaan om een lasthebber ad hoc aan te duiden, zal het vereiste dat de strafvordering is ingesteld uit artikel 2bis V.T.Sv. moeten worden gehaald.

Voorts lijkt het weinig realistisch van de correctionele rechtbank te verlangen kennis te nemen van een zaak, louter en alleen met het oog op het aanstellen van een lasthebber ad hoc, wanneer geenszins zeker is dat deze zaak ooit bij de correctionele rechtbank ten gronde zal worden aanhangig gemaakt. Immers, op het einde van het opsporingsonderzoek kan het openbaar ministerie nog altijd beslissen niet te dagvaarden, maar integendeel te seponeren of één of andere wijze van afdoening buiten proces (zoals de minnelijke schikking of de strafbemiddeling) te benaarstigen. En op het einde van het gerechtelijk onderzoek kan de raadkamer beslissen de zaak niet te verwijzen naar de feitenrechter, maar integendeel de rechtspersoon buiten vervolging te stellen of de gunst van de opschorting van de uitspraak te verlenen.

Het is tenslotte totaal onrealistisch te veronderstellen dat, wanneer tijdens het gerechtelijk onderzoek naar een misdaad (bv. een valsheid in geschrifte) die op dat ogenblik per definitie nog niet is gecorrectionaliseerd, zich de noodzaak opdringt een lasthebber ad hoc aan te stellen, dit dan zou gebeuren door ... het hof van assisen. Dit hof is immers geen permanent hof, maar moet per zaak worden samengesteld. En de kans dat een valsheid in geschrifte daadwerkelijk voor dat hof van assisen zou worden aanhangig gemaakt, is werkelijk nihil. ${ }^{31}$

Io. In de praktijk is dan ook de gewoonte ontstaan dat ook de onderzoeksrechter of de raadkamer een lasthebber ad hoc aanduidt. Binnen de huidige regeling getuigt dit van gezond verstand.

Wat de onderzoeksrechter betreft die duidelijk geen 'rechtbank' is 'die bevoegd is om kennis te nemen van de strafvordering', is deze praktijk op zijn zachtst gezegd praeter legem en eigenlijk zelfs contra legem. In de mate de wetgever beslist een wettelijke regeling van de lasthebber ad hoc aan te houden, verdient het m.i. dan ook aanbeveling te bepalen dat de bevoegde rechter deze is, bij wie de zaak aanhangig is op het ogenblik van het ontstaan - of vaststellen - van het belangenconflict: de onderzoeksrechter, het onderzoeksgerecht of het vonnisgerecht. ${ }^{32}$

In de mate de aanduiding van een lasthebber ad hoc bovendien ook mogelijk zou moeten zijn tijdens een opsporingsonderzoek, moet de wetgever bovendien de ne-

3I Zie F. DERUYCK, 'Over de correctionalisering van misdaden: pleidooi voor “intelligent design”', in De wet voorbij. Liber Amicorum Luc Huybrechts, Antwerpen-Oxford, Intersentia, 2010, I23 e.v.

32 Zie in deze zin H. VAN BAVEL, 'De wet van 4 mei 1999 tot invoering van de strafrechtelijke verantwoordelijkheid van rechtspersonen', A.J.T., I999-2000, 224. 
telige vraag oplossen wie in dat geval de lasthebber ad hoc kan aanduiden. Nu het openbaar ministerie niet enkel de leiding heeft van het opsporingsonderzoek maar ook de strafvordering uitoefent, komt de procureur des Konings - als partij33 in de het mogelijk latere strafproces tegen de rechtspersoon - daarvoor niet in aanmerking.

II. Vanuit het perspectief van de rechten van verdediging is het eerder bedenkelijk dat dezelfde vonnisrechter die over de verdachte rechtspersoon zal oordelen, in vele gevallen tevens over die rechtspersoon ambtshalve een lasthebber ad hoc zal aanstellen om de rechtspersoon te vertegenwoordigen. Hierna zal blijken dat het statuut en de bevoegdheden van de lasthebber ad hoc dit onbehagen nog vele malen versterken.

Artikel 2bis V.T.Sv. bepaalt evenwel, dat de lasthebber ad hoc ofwel ambtshalve, ofwel op verzoekschrift kan worden aangesteld. In de Senaatscommissie voor Justitie werd opgemerkt dat zulk verzoekschrift enkel kan uitgaan van de rechtspersoon zelf, omdat enkel hij er een belang bij heeft. ${ }^{34}$ Het lijkt nochtans niet uitgesloten dat ook anderen daar een belang bij kunnen hebben, bv. medebeklaagden die weliswaar voor de rechtspersoon werkzaam zijn, maar deze niet kunnen vertegenwoordigen. ${ }^{35}$ In de rechtspraak zijn verzoekschriften van andere belanghebbenden reeds ontvankelijk verklaard. ${ }^{36}$

In het oorspronkelijke wetsvoorstel was de mogelijkheid van een verzoekschrift van de betrokken rechtspersoon nochtans niet voorzien. ${ }^{37}$ Tijdens de bespreking in de Senaatscommissie voor Justitie werd evenwel een amendement ingediend, dat er toe strekte te bepalen dat de vennootschap altijd vooraf bij verzoekschrift de aanwijzing van een lasthebber ad hoc kan vragen..$^{38}$

De reden daarvoor lag - opmerkelijk genoeg - niet zozeer in de bekommernis om de rechtspersoon bij de aanwijzing van een lasthebber ad hoc te betrekken. Veeleer speelde het gegeven dat, als de feitenrechter de lasthebber ad hoc ambtshalve aanstelt, hij dit uiteraard slechts bij het begin van het proces kan doen, zodat de zaak dan niet in staat is. In de praktijk volgt op de aanstelling van de lasthebber ad hoc tijdens de eerste zitting inderdaad steevast een voortzetting van de zaak, teneinde de pas aangestelde lasthebber ad hoc de gelegenheid te geven van de zaak kennis te

33 In de praktijk veelal, ondanks alle mogelijke theoretische beschouwingen, als tegenpartij van de verdachte rechtspersoon.

Zie m.b.t. de hoedanigheid van het openbaar ministerie in het strafproces Cass. I9 december 2012, AR P.I2.I3Io.F, waarin werd benadrukt dat het openbaar ministerie wel partij is in het strafproces, maar niet op dezelfde wijze als de andere partijen: de opdracht van het openbaar ministerie beperkt zich immers niet tot die van aanklager, maar het komt ook tussen in het geding om de rechter een rechterlijke oplossing voor te stellen.

34 Verslag van de Senaatscommissie voor Justitie, Parl. St., Senaat, I998-99, nr. I-I2I7/6, p. 75.

35 A. DE NAUW en F. DERUYCK, 'De strafrechtelijke verantwoordelijkheid van rechtspersonen', RW I999-2000, 9I3.

36 Zie de onuitgegeven rechtspraak geciteerd door S. DE MEULENAER en P. WAETERINCKX, 'De lasthebber ad hoc in het straf(proces)recht: lastiger dan gedacht', RW 2003-2004, 408, nr. 30.

37 Zie de tekst van het in het oorspronkelijk wetsvoorstel voorgenomen artikel 2bis V.T.Sv., Parl. St., Senaat, I998-99, nr. I-I2I7/I, p. I7 (artikel II).

38 Amendement nr. 28 van de Heer VANDENBERGHE, Parl. St., Senaat, I998-99, nr. I-I2I7/4, p. 4. 
nemen. Door evenwel een voorafgaand verzoekschrift van de betrokken partij toe te laten en te honoreren, zou de zaak bij het begin van het proces in staat zijn en zou dergelijk tijdverlies worden vermeden. ${ }^{39}$

De mogelijkheid voor de rechtspersoon om de aanstelling van een lasthebber ad hoc bij verzoekschrift te vragen, heeft daarentegen wel degelijk een rol gespeeld bij de beantwoording door het toenmalig Arbitragehof (thans Grondwettelijk Hof) ${ }^{40}$ van de volgende prejudiciële vraag: schendt artikel 2 bis V.T.Sv. de artikelen Io en II van de Grondwet, ${ }^{4 \mathrm{I}}$ in samenhang met artikel 6 van het EVRM, ${ }^{42}$ door op een discriminerende manier de rechtspersoon het recht te ontnemen om voor de strafrechter te verschijnen en te worden verdedigd door een advocaat van zijn keuze?

Zonder de mogelijkheid een verzoekschrift in te dienen, zou dat inderdaad het geval zijn, aldus het Hof:

'De aanwijzing van een lasthebber ad hoc zou onevenredige gevolgen hebben indien zij de rechtspersoon stelselmatig de mogelijkheid zou ontnemen zijn vertegenwoordiger te kiezen. Dat is te dezen niet het geval, vermits artikel 2 bis de rechtspersoon toestaat zelf die aanwijzing bij verzoekschrift te uragen en hij zijn lasthebber ad hoc aan de rechter kan voorstellen.'43

Dat moge dan wel zo zijn, maar het indienen van een verzoekschrift verzekert geenszins dat diegene die door de rechtspersoon wordt voorgesteld, daadwerkelijk als lasthebber ad hoc wordt aangeduid. In de doctrine worden vele redenen opgesomd, die in de praktijk wel eens worden aangenomen om de voorgestelde persoon niet aan te duiden als lasthebber ad hoc (bv. contractuele, familiale of vriendschappelijke relaties met de natuurlijke persoon die ook wordt vervolgd), tot en met het gebrek aan juridische kennis van de voorgestelde lasthebber ad hoc toe ${ }^{44}$... Voor sommigen makkt zelfs het feit zelve dat iemand wordt voorgesteld door de vervolgde rechtspersoon hem a priori a.h.w. 'verbrand' en dus ongeschikt om als lasthebber ad hoc te fungeren. Op die manier is men ver verwijderd van de waarborg, die het Grondwettelijk Hof ziet in de mogelijkheid om zelf een verzoekschrift in te dienen.

I2. Daarbij rijst, opnieuw vanuit het oogpunt van de rechten van verdediging, uiteraard de vraag of de aanstelling van een lasthebber ad hoc door de rechter vatbaar is voor hoger beroep.

Bij de beantwoording van die vraag doet het er overigens niet toe of het nu gaat om een lasthebber ad hoc die door de rechter werd aangesteld nadat hij een verzoekschrift tot aanstelling van een welbepaalde persoon als lasthebber ad hoc heeft verworpen, dan wel om een lasthebber ad hoc die uit eigen beweging door de

39 Verslag van de Senaatscommissie voor Justitie, Parl. St., Senaat, I998-99, nr. I-I2I7/6, p. 75.

40 Zie artikel 6 van de bijzondere wet van 2I februari 2oro tot aanpassing van verschillende bepalingen aan de benaming 'Grondwettelijk Hof', BS 26 februari 2010.

$4 \mathrm{I} \quad$ Resp. het gelijkheidsbeginsel en het verbod van discriminatie.

42 Meer bepaald het eerlijk proces, in i.h.b. de rechten van verdediging.

43 Arbitragehof, arrest nr. I9o/2006 d.d. 5 december 2006, overweging B.7, RABG 2007, 379, noot P. WAETERINCKX, 'De lasthebber ad hoc, nog steeds lastiger dan gedacht ...'.

44 P. HELSEN, 'De lasthebber ad hoc in het strafrecht: een eerste verkenning op braakliggend terrein', T. Strafr., 2003, p. 6-7, met verdere verwijzingen. 
rechter werd aangesteld. In beide gevallen kan de rechtspersoon zich gegriefd voelen: ofwel door het aanduiden van een lasthebber ad hoc als dusdanig, ofwel door de keuze van de rechter van de persoon die als lasthebber ad hoc wordt aangeduid.

Tegen een tussenvonnis van de feitenrechter staat hoger beroep open. Dat wordt niet betwist daar vonnissen in eerste aanleg, inclusief vonnissen alvorens recht te doen, vatbaar zijn voor beroep (artikel ro50 en I046 Ger.W.). Nu de aanstelling van een lasthebber ad hoc bij tussenvonnis gebeurt, is deze aanstelling inderdaad vatbaar voor hoger beroep..$^{45}$

Indien het beroep wordt ingewilligd en de aanstelling van de lasthebber ad hoc in hoger beroep geen stand houdt, zal het hof van beroep, bij toepassing van artikel 2I5 Sv., de zaak evoceren en er in eerste en laatste aanleg uitspraak over doen. ${ }^{46}$

Of ook hoger beroep bij de kamer van inbeschuldigingstelling mogelijk is tegen een beschikking van de onderzoeksrechter waarbij een lasthebber ad hoc wordt aangeduid, is al minder voor de hand liggend. Sommigen werpen tegen dat de wet in dergelijk hoger beroep niet voorziet ${ }^{47}$. Dit overtuigt m.i. niet, nu de wet om te beginnen al niet voorziet in de mogelijkheid voor de onderzoeksrechter om een lasthebber ad hoc aan te duiden. Er zijn dan ook reeds meerdere uitspraken van kamers van inbeschuldigingstelling die het hoger beroep tegen een beschikking van de onderzoeksrechter tot aanstelling van een lasthebber ad hoc terecht ontvankelijk hebben verklaard. $4^{8}$

Ook wat de aanduiding van een lasthebber ad hoc door de raadkamer betreft, is de situatie onduidelijk. Voor de inverdenkinggestelde is immers maar in welbepaalde

45 In deze zin Luik 29 maart 2006, T. Strafr. 2006, 274; Gent I maart 2002, RW 2002-2003, I548, noot A. SMETS, 'De wet van 4 mei 1999 tot invoering van de strafrechtelijke verantwoordelijkheid van rechtspersonen en de lasthebber ad hoc: een belangenconflict?'; Gent I5 januari 2002, NJW 2002, 63; Corr. Oudenaarde 6 juni 2003, RABG 2004, 37I, noot D. DE BACKER, 'De aanwijzing van een lasthebber ad hoc: mogelijkheid of verplichting?'.

46 Zie nogmaals Gent 15 januari 2002, NJW 2002, 63.

47 P. HELSEN, 'De lasthebber ad hoc in het strafrecht: een eerste verkenning op braakliggend terrein', T. Strafr., 2003, 8; D. MATRAY en J. OVERATH, J. 'Le mandataire ad hoc dans la responsabilité pénale des personnes morales', in Liber Amicorum Jean-Pierre De Bandt, Brussel, Bruylant, 2004, 477; S. VAN DYCK en V. FRANSSEN, 'De rechtspersoon als strafbare dader: een grondige analyse van tien jaar wetgeving, rechtspraak en rechtsleer', T.R.V., 2009, 4I, nr. I53.

48 K.I. Gent 27 maart 200I, onuitg.; K.I. Luik 23 april 200I, onuitg.

In een arrest van $\mathrm{I} 6$ oktober 2007 heeft het Hof van Cassatie wel het cassatieberoep tegen een arrest van de Antwerpse kamer van inbeschuldigingstelling, die zich in beroep had uitgesproken over de beschikking van de onderzoeksrechter die een lasthebber ad hoc had aangeduid, afgewezen als voorbarig en dus niet ontvankelijk: Cass. I6 oktober 2007, nr. P.07.0774.N. Het gaat immers niet om een definitieve beslissing als bedoeld in artikel $4 \mathrm{I} 6, \mathrm{I}^{\text {ste }}$ lid Sv. (thans art. $4 \mathrm{I} 8 \mathrm{~Sv}$.) en het bestreden arrest deed evenmin uitspraak met toepassing van artikel 235 bis Sv.

Als de kamer van inbeschuldigingstelling evenwel, in het kader van een hoger beroep tegen een beschikking van de onderzoeksrechter overeenkomstig artikel 6rquater Sv., geroepen is ook uitspraak te doen over de regelmatigheid van de rechtspleging met toepassing van artikel 235 bis Sv., dient het hof ook uitspraak te doen over de aangevoerde onregelmatigheid van de aanstelling van een lasthebber ad hoc: Cass. I6 oktober 2007, nr. P.07.0895.N. 
gevallen een hoger beroep mogelijk tegen beschikkingen van de raadkamer ${ }^{49}$ en het is niet evident om de aanstelling van een lasthebber ad hoc in één van die gevallen onder te brengen. Wellicht zou de aanstelling van een lasthebber ad hoc kunnen worden beschouwd als een onregelmatigheid die kleeft aan de verwijzingsbeschikking zelf: door over de rechtspersoon, tegen diens wil, een lasthebber ad hoc aan te stellen ter waarneming van zijn belangen, worden zijn rechten van verdediging immers geschonden..$^{\circ}$

Tenslotte rijst de vraag, wie het hoger beroep tegen de aanstelling van een lasthebber ad hoc kan aantekenen. Het zou van enig cynisme getuigen voor te houden dat, eenmaal de lasthebber ad hoc is aangeduid, hij de enige is die een rechtsmiddel zou kunnen aanwenden tegen zijn eigen aanstelling ... ${ }^{\mathrm{I}}$

Het moge duidelijk zijn dat de rechtspersoon over wie een lasthebber ad hoc wordt aangesteld hoger beroep kan aantekenen, ofwel zelf, ofwel via een door hem gemandateerde advocaat. De aanduiding van een lasthebber ad hoc heeft betrekking op de vertegenwoordiging van de rechtspersoon in de verdere procedure, doch niet in de procedure die precies over zijn aanstelling gaat. Dus ook wanneer de aanstelling van een lasthebber ad hoc door de rechtbank uitvoerbaar bij voorraad wordt verklaard, is hoger beroep door de rechtspersoon zelf mogelijk. ${ }^{52}$

Daarentegen lijkt de rechtspraak niet te aanvaarden dat de natuurlijke persoon die de rechtspersoon kan vertegenwoordigen en samen met deze rechtspersoon wordt vervolgd, hoger beroep zou kunnen aantekenen tegen de aanstelling van een lasthebber ad hoc over deze rechtspersoon. Deze beslissing belangt immers enkel de rechtspersoon aan, zodat het hoger beroep van de natuurlijke persoon bij gebrek aan belang niet-ontvankelijk is. ${ }^{53}$

I3. Een laatste kwestie m.b.t. de aanstelling van de lasthebber ad hoc, die soms in de praktijk opduikt, is de vraag of de lasthebber ad hoc lopende de strafproce-

49 Meer bepaald ingeval van de volgende excepties: de onbevoegdheid van de raadkamer, de niet-ontvankelijkheid of het verval van de strafvordering, onregelmatigheden, verzuimen of nietigheden m.b.t. handelingen van het onderzoek of de bewijsverkrijging, alsmede m.b.t. de verwijzingsbeschikking zelf (art. I35, § 2 Sv.).

50 Het Hof van Cassatie heeft in een recent arrest bevestigd dat de inverdenkinggestelde hoger beroep kan instellen tegen een beschikking waarbij hij, naar zijn mening, wordt verwezen zonder dat zijn recht van verdediging geëerbiedigd werd (Cass. 2I mei 20I2, AR P.I2.0070.F; vgl. reeds Cass. 8 januari 2003, AR P.02.I486.F).

5I Een consequente toepassing van de uitvoerbaarheid bij voorraad van de beslissing, waarbij de lasthebber ad hoc werd aangeduid, zou dit nochtans tot gevolg hebben: zie P. HELSEN, 'Hoger beroep tegen de uitvoerbaar bij voorraad aangestelde lasthebber ad hoc' (noot onder Antwerpen 22 februari 2006), RW 2009-2010, 584, nr. 5 .

52 Gent 24 oktober 2002, onuitg. doch geciteerd door P. HELSEN, 'De lasthebber ad hoc in het strafrecht: een eerste verkenning op braakliggend terrein', T. Strafr., 2003, 7, voetnoot 39.

53 Cass. Io februari 20I0, AR P.o9.I28I.F (onontvankelijk hoger beroep van de vaste vertegenwoordiger van de vennootschap die het mandaat van afgevaardigde bestuurder van de rechtspersoon uitoefent en die samen met die rechtspersoon wordt vervolgd); Antwerpen, 22 februari 2006, RW 2009-2010, 582 (onontvankelijk hoger beroep van de zaakvoerder van een vennootschap die samen met de vennootschap wordt vervolgd). 
dure kan worden vervangen. In de regel duurt de aanstelling van de lasthebber ad hoc voort totdat er een definitieve beslissing is genomen in de strafprocedure tegen die rechtspersoon. Het is evenwel niet uitgesloten dat de lasthebber ad hoc zelf van oordeel is niet meer te kunnen optreden wegens een belangenconflict (bv. via het kantoor, waaraan hij als advocaat verbonden is) of dat de rechtspersoon wegens een verstoorde vertrouwensrelatie een andere lasthebber ad hoc wenst.

Verzoekschriften tot vervanging van de lasthebber ad hoc, gericht aan de rechtbank die de lasthebber ad hoc had aangesteld, zijn in de praktijk al wel ontvankelijk verklaard (daarom niet altijd gegrond, maar daar gaat het hier niet over). ${ }^{54}$ De vraag door wie dergelijk verzoekschrift tot vervanging moet worden ondertekend, is niet zo eenvoudig te beantwoorden. De lasthebber ad hoc is per definitie al in functie wanneer om zijn vervanging wordt gevraagd, zodat zou kunnen voorgehouden worden dat hij het verzoekschrift tot vervanging moet ondertekenen. Als het verzoek tot vervanging van de lasthebber ad hoc uitgaat, is dat inderdaad het geval. Doch wanneer de rechtspersoon om de vervanging verzoekt tegen de wil van de lasthebber ad hoc, moet m.i. aangenomen worden dat een orgaan van de rechtspersoon (of een daartoe gemandateerde advocaat van de rechtspersoon) het verzoekschrift tot vervanging kan ondertekenen. ${ }^{55}$

In de mate over dergelijk verzoekschrift uitspraak werd gedaan, ligt het voor de hand dat tegen een eventuele weigering tot vervanging van de lasthebber ad hoc hoger beroep kan worden aangetekend, net zoals tegen de oorspronkelijke aanstelling van de lasthebber ad hoc hoger beroep mogelijk is.

\section{I.I.2 Wie wordt als lasthebber ad hoc aangesteld?}

I4. Tijdens de parlementaire bespreking van artikel 2 bis V.T.Sv. - m.b.t. de vertegenwoordiging - werd met geen woord gerept over de vraag wie nu best wordt aangeduid als lasthebber ad hoc. Uit de bespreking van de artikelen 152 en I85 Sv. - m.b.t. de verschijning - kan evenwel enige lering getrokken worden.

De wetgever heeft een tijdlang met de idee gespeeld om de rechter de mogelijkheid te geven de persoonlijke verschijning van de rechtspersoon te bevelen en te dien einde het orgaan of een andere persoon van de rechtspersoon aan te duiden, die ingevolge dat bevel moet verschijnen (zie hierna, nr. 33). In dat kader werd geopperd dat de rechter in zulk geval best een orgaan of een lid van een orgaan zou aanwijzen, of anders een werknemer met een belangrijke functie zoals de financieel directeur of de administratief directeur. ${ }^{56}$

54 Zie bv. Gent Io ${ }^{\text {de }}$ kamer, arrest nr. 2009/I494 d.d. 24 april 2009, onuitg.

55 Het is tenslotte ook denkbaar dat zowel de rechtspersoon als de lasthebber ad hoc om vervanging verzoekt, in welk geval zowel een orgaan van de rechtspersoon als de lasthebber ad hoc het daartoe strekkende verzoekschrift kan ondertekenen.

56 Verslag namens de Senaatscommissie voor Justitie, Parl. St., Senaat, I998-99, nr. I-I2I7/6, p. 87. 
Men zou dan ook kunnen verwacht hebben dat als lasthebber ad hoc een gelijkaardige persoon van binnen de rechtspersoon wordt aangeduid. In de meeste verzoekschriften tot aanstelling van een lasthebber ad hoc wordt trouwens een andere bestuurder van de rechtspersoon voorgesteld, die niet samen met de rechtspersoon wordt vervolgd (en die soms wel, soms niet wordt aanvaard door de rechter: zie hierboven, nr. II).

Bij ambtshalve aanstellingen van een lasthebber ad hoc gaat het er in de praktijk evenwel heel anders aan toe. Er is immers - om redenen die ik tot op vandaag niet begrijp een praktijk ontstaan waarbij aan de balies wordt gevraagd een lijst op te stellen van advocaten, die bereid zijn als lasthebber ad hoc te worden aangeduid. Indien dan ambtshalve wordt overgegaan tot het aanduiden van een lasthebber ad hoc, wordt één van de op die lijst voorkomende advocaten (letterlijk de volgende) aangeduid.

Dergelijke regeling tart het gezond verstand. De rechtspersoon die verdachte is of reeds vervolgd wordt, heeft ongetwijfeld (via de raad van bestuur) een advocaat aangesteld om zijn belangen in de strafprocedure te behartigen. Wat voor zin heeft het dan, dat daar door de rechter een andere advocaat aan wordt toegevoegd? Wat is dan de verhouding tussen die twee advocaten, de ene - als raadsman - gemandateerd door de raad van bestuur, de andere - als lasthebber ad hoc - aangesteld door de rechter? Op deze vragen wordt hierna, bij de bespreking van het statuut en de bevoegdheden van de lasthebber ad hoc, nog nader ingegaan.

I5. Een bijzonder geval wordt gevormd in geval van faillissement van de vervolgde vennootschap. Dan kan, volgens de feitenrechtspraak, de curator van het faillissement niet de lasthebber ad hoc zijn, rekening houdend met het belangenconflict in verband met zijn gerechtelijk mandaat ${ }^{57}$. De reeds aangestelde lasthebber ad hoc blijft dus bevoegd, tot er een definitieve beslissing is gevallen over de strafvordering t.a.v. de rechtspersoon..$^{8}$

\section{I.I.3 Is de aanstelling van de lasthebber ad hoc een verplichting?}

I6. Op basis van de tekst van de wet lijkt er, op het eerste gezicht, weinig twijfel over te bestaan dat de rechter geen beoordelingsvrijheid heeft. Inderdaad, luidens artikel 2 bis V.T. Sv. wijst de rechter, ingeval de strafvordering wegens dezelfde of samenhangende feiten is ingesteld tegen de rechtspersoon en tegen de natuurlijke persoon die bevoegd is om de rechtspersoon te vertegenwoordigen, een lasthebber ad hoc aan om de rechtspersoon te vertegenwoordigen. De vaststelling dat zowel de rechtspersoon als de natuurlijke persoon worden vervolgd, leidt dan a.h.w. automatisch tot het aanstellen van een lasthebber ad hoc.

\footnotetext{
57 Brussel 4 oktober 20II, Dr.pén.entr. 20II, 339. Vgl. Corr. Brussel I7 februari 20I2, Dr.pén.entr. 20I3, I03 en Corr. Brussel 27 maart 20I2, T.B.H. 2012, 540 (weergave D. LIBOTTE).

58 Antwerpen 7 mei 2008, R.W., 2008-2009, I520, noot P. HELSEN.
} 
Een blik op de parlementaire voorbereiding doet evenwel redelijke twijfel ontstaan. Zoals hierboven werd verduidelijkt (zie nr. II), bepaalt artikel 2 bis V.T.Sv. dat de rechter de lasthebber ad hoc ambtshalve of op verzoekschrift aanduidt.

Tijdens de bespreking in de Kamercommissie voor Justitie werd aan de vertegenwoordiger van de minister van Justitie de vraag gesteld of het woord 'ambtshalve' inhoudt dat de rechtbank steeds een lasthebber ad hoc moet aanstellen, telkens zich de situatie voordoet dat de strafvordering is ingesteld tegen zowel de rechtspersoon als tegen de natuurlijke persoon die de rechtspersoon kan vertegenwoordigen. Het antwoord luidde dat het woord 'ambtshalve' betekent dat de rechter de bevoegdheid heeft om na te gaan of het aangewezen is om een lasthebber ad hoc aan te wijzen, zonder hiervoor een verzoek van de betrokken partijen te hebben ontvangen. ${ }^{59}$

Hieruit blijkt niet alleen een voorkeur voor een initiatief vanwege de partijen, doch ook dat, zonder zulk initiatief, de rechter weliswaar ook ambtshalve een lasthebber ad hoc kan aanduiden, maar daarbij wel een appreciatiebevoegdheid heeft en dus ook kan besluiten dat het niet aangewezen is een lasthebber ad hoc aan te duiden.

I7. De rechtspraak en de rechtsleer blijven over deze kwestie, tot op de dag van vandaag, erg verdeeld.

Zij die een verplichte aanduiding van een lasthebber ad hoc voorstaan, wijzen vooreerst op de affirmatieve toon van artikel 2 bis V.T.Sv.

Zij voeren voorts aan dat er altijd een mogelijke tegenstrijdigheid van belangen tussen de rechtspersoon en de natuurlijke persoon bestaat. ${ }^{60}$

Dat belangenconflict zou, bij vervolging wegens onopzettelijk gepleegde misdrijven, zelfs a.h.w. ingebakken zijn in de materieelrechtelijke regeling van de strafrechtelijke verantwoordelijkheid van rechtspersonen in artikel $5 \mathrm{Sw} .{ }^{6}$ Het tweede lid van dit wetsartikel bepaalt immers dat bij onopzettelijk gepleegde misdrijven slechts één van beide vervolgde personen, rechtspersoon óf natuurlijke persoon, kan worden veroordeeld, met name diegene die de zwaarste fout heeft begaan. ${ }^{62}$

Doch ook bij de vervolging van opzettelijk gepleegde misdrijven - in welk geval beide vervolgde personen, zowel de natuurlijke persoon als de rechtspersoon, kun-

59 Verslag namens de Kamercommissie voor Justitie, Parl. St., Kamer, I998-99, nr. 2093/5, p. 37-38.

6o Zo P. HELSEN, 'De lasthebber ad hoc in het strafrecht: een eerste verkenning op braakliggend terrein', T. Strafr., $2003,6$.

6I In deze zin Luik 3 februari 20II, Dr.pén.entr. 20II, 97; Luik 28 oktober 2009, Dr.pén.entr. 20I0, 23; Corr. Gent 5 februari 2002, N.J.W. 2003, 167.

62 In de memorie van toelichting bij het voorontwerp van wet, dat nooit werd ingediend (zie hierboven, voetnoot 3) maar wel aan de Raad van State werd voorgelegd, staat als onwaarschijnlijke motivering voor deze regeling: 'Aldus wordt vermeden dat, hetzij de rechtspersoon, hetzij de natuurlijke persoon, a priori een inschatting kan maken van het strafrechtelijke risico.' (memorie van toelichting bij het voorontwerp van wet, geciteerd in het advies van de Raad van State, Parl. St., Senaat, I998-99, nr. I-I2I7/6, p. I23). De Raad van State haastte zich om op te merken dat deze passage volkomen in strijd is met het wettelijkheidsbeginsel, dat geen andere reden van bestaan heeft dan iedereen in staat te stellen dat risico in te schatten ... 
nen worden veroordeeld - zou een mogelijke tegenstrijdigheid van belangen nooit uit te sluiten zijn.

M.i. is de aanduiding van een lasthebber ad hoc geen verplichting die zich automatisch zou opdringen aan de rechter, telkens hij vaststelt dat de strafvordering wegens dezelfde of samenhangende feiten is ingesteld tegen de rechtspersoon en tegen de natuurlijke persoon, die bevoegd is om hem te vertegenwoordigen. ${ }^{63}$

Het is immers zeer wel denkbaar dat er tussen de rechtspersoon en de natuurlijke persoon geen enkel belangenconflict bestaat. ${ }^{64}$ Dat is in de praktijk overigens wel vaker het geval, bv. wanneer zowel de rechtspersoon als de natuurlijke persoon in zijn verdediging aanvoert dat er geen misdrijf is (omdat de constitutieve bestanddelen niet verenigd zijn) of dat de strafvordering vervallen is (door verjaring).

Het bepaalde van artikel $5,2^{\text {de }}$ lid Sw. doet daaraan niets af. Het is toch niet omdat in dat artikel wordt bepaald dat bij onopzettelijke misdrijven enkel diegene die de zwaarste fout heeft begaan kan veroordeeld worden, dat het verweer van rechtspersoon en natuurlijke persoon noodzakelijkerwijze moet gaan over de vraag wie nu de zwaarste fout heeft begaan? Het is toch mogelijk dat zowel de rechtspersoon als de natuurlijke persoon als verweer voert dat er geen sprake is van een gebrek aan voorzichtigheid of voorzorg, zodat de kwestie van de afweging van de onderlinge fouten zelfs niet aan bod komt?

Waar in concreto geen belangenconflict is, dient het m.i. niet te worden opgelost omdat het in abstracto wel denkbaar zou zijn.

I8. En zelfs als er een concreet belangenconflict bestaat tussen de rechtspersoon en de natuurlijke persoon die hem kan vertegenwoordigen, is er m.i. niet steeds nood aan het aanstellen van een lasthebber ad hoc.

Zo is het zeer wel mogelijk dat, naast deze vervolgde natuurlijke persoon die bevoegd is om de rechtspersoon te vertegenwoordigen, er nog andere natuurlijke personen zijn die niet worden vervolgd en die evenzeer bevoegd zijn om de rechtspersoon te vertegenwoordigen, bv. in geval slechts één bestuurder wordt vervolgd samen met de rechtspersoon, doch de andere bestuurders niet. Het is dan geenszins vereist dat een lasthebber ad hoc wordt aangesteld om over de belangen van de rechtspersoon, die mogelijks zouden strijden met deze van de vervolgde natuurlijke persoon, te waken. Die andere natuurlijke personen die eveneens bevoegd zijn om de rechtspersoon te vertegenwoordigen, kunnen daarvoor immers het nodige doen.

Dat wordt door sommigen wel eens anders gezien, ${ }^{65}$ waarbij dan wél wordt opgemerkt dat het in dergelijk geval ondenkbaar lijkt dat de lasthebber ad hoc de wensen van het bestuursorgaan naast zich zou neerleggen en op eigen houtje de te volgen verdedigingsstrategie zou bepalen. Dat laatste wil ik op zich best onderschrijven, maar

63 Zie vroeger reeds A. DE NAUW en F. DERUYCK, 'De strafrechtelijke verantwoordelijkheid van rechtspersonen', RW I999-2000, 912.

64 In deze zin Gent I maart 2002, R.W. 2002-2003, 1548, noot A. SMETS.

65 Zie P. HELSEN, 'De lasthebber ad hoc in het strafrecht: een eerste verkenning op braakliggend terrein', T. Strafr., 2003, 9. 
de vraag rijst of het gelet op het statuut, de taak en de bevoegdheden van de lasthebber ad hoc (zie hierna, nr. Ig e.v.) werkelijk zo ondenkbaar is dat de lasthebber ad hoc zijn eigen koers vaart. Bovendien rijst, als de lasthebber ad hoc toch de wensen van het bestuursorgaan zou moeten uitvoeren, de vraag waarom dan in de eerste plaats een lasthebber ad hoc diende te worden aangesteld: dan kan het bestuursorgaan toch een zelf gekozen raadsman met de uitvoering van die wensen mandateren?

Voorts rijst de vraag of er nog wel een lasthebber ad hoc dient te worden aangesteld wanneer voor de rechtspersoon en de natuurlijke persoon die hem kan vertegenwoordigen, verschillende raadslieden optreden. Waar voor sommige rechters zulks niet afdoet aan de verplichting om ook in dat geval een lasthebber ad hoc aan te duiden, zien veel andere rechters in de praktijk integendeel af van het aanstellen van een lasthebber ad hoc wanneer zowel de rechtspersoon als de natuurlijke persoon een eigen raadsman hebben. ${ }^{66}$

In strafzaken worden belangenconflicten tussen vervolgde partijen immers gebruikelijk opgelost door afzonderlijke raadslieden, die elk de deontologische plicht hebben om de belangen van hun cliënt naar best vermogen te verdedigen en dus niet mee te spelen in de strategie van een medeverdachte wanneer dit de belangen van hun cliënt zou kunnen schaden.

\section{I.I.4 Wat is het statuut, de taak en de bevoegdheid van de lasthebber ad hoc?}

I9. In het oorspronkelijke wetsvoorstel was sprake van het aanwijzen van een 'gerechtelijk lasthebber' ${ }^{67}$ In de Senaatscommissie voor Justitie werd evenwel een amendement ingediend om deze woorden te vervangen door 'een lasthebber ad hoc'. ${ }^{68}$

De verantwoording die voor deze - meer dan terminologische - wissel werd gegeven tijdens de bespreking in de Senaatscommissie voor Justitie, doet nog steeds de wenkbrauwen fronsen:

"Een lid is van oordeel dat de woorden "gerechtelijk lasthebber" best vervangen worden door de woorden "lasthebber ad hoc". Zo niet kan er verwarring bestaan, aangezien de advocaat ook als een gerechtelijk lasthebber zou kunnen worden beschouwd. ${ }^{69}$

Een gerechtelijk lasthebber is iemand die, op last van een rechtbank, een bepaald mandaat waarneemt en daarover aan de rechtbank verantwoording verschuldigd is

66 In deze laatste zin: Corr. Leuven 22 februari 2006, T. Strafr. 2006, 228. Vgl. in dezelfde zin F. LUGENTZ en O. KLEES, 'Le point sur la responsabilité pénale des personnes morales', R.D.P. 2008, 209.

67 Zie artikel II van het wetsvoorstel VANDENBERGHE c.s. tot invoering van een artikel 2bis V.T.Sv., Parl. St., Senaat, I998-99, nr. I-I2I7/I, p. I7.

68 Amendement nr. 27 van Mevr. JEANMOYE en Mevr. DELCOURT-PÊTRE, Parl. St., Senaat, I998-99, nr. I-I2I $/ 4$, p. 4.

69 Verslag namens de Senaatscommissie voor Justitie, Parl. St., Senaat, I998-99, nr. I-I2I7/6, p. 75. 
(bv. een curator). Het moge duidelijk zijn dat de advocaat die de verdachte bijstaat in de strafprocedure geenszins verantwoording verschuldigd is aan de strafrechter over de manier waarop hij die bijstand heeft ingevuld. De strafrechter heeft in zijn vonnis overigens voldoende ruimte zich daarover uit te spreken ...

De poging van de wetgever om, door het gebruik van een andere terminologie, de lasthebber ad hoc over een rechtspersoon goed te onderscheiden van de advocaat van die rechtspersoon, is dus op zijn minst onhandig te noemen. Hierna zal blijken dat dit onderscheid ook zinloos geworden is.

20. Wat is immers het statuut van de lasthebber ad hoc? Artikel 2bis V.T.Sv. zegt in fine: 'om hem [bedoeld wordt: de rechtspersoon] te vertegenwoordigen'.

Uit de hierna volgende rechtspraak - eerst die van het Grondwettelijk Hof, nadien die van het Hof van Cassatie - blijkt evenwel, dat onder 'vertegenwoordigen' veel meer moet worden begrepen dan optreden namens iemand of diens beslissingen uitvoeren. De taken en bevoegdheden van de lasthebber ad hoc zijn veel en veel ruimer dan dat.

\section{I.I.4.I Lering uit de rechtspraak van het Grondwettelijk Hof}

2I. In het hierboven reeds aangehaalde arrest van 5 december 2006 waarin het toenmalige Arbitragehof de verenigbaarheid van artikel 2 bis V.T.Sv. met de artikelen Io en II van de Grondwet, in samenhang gelezen met artikel 6 van het EVRM, diende na te gaan (zie hierboven, nr. II), heeft het Arbitragehof m.b.t. het statuut en de taak van de lasthebber ad hoc al een eerste tip van de sluier gelicht:

'De lasthebber ad hoc zal ten slotte doorgaans een advocaat zijn of een persoon die zich tot een advocaat zal moeten wenden om de verdediging van de rechtspersoon te verzekeren, zodat de laatstgenoemde zal worden verdedigd door een persoon wiens deontologie hem verbiedt om tegenstrijdige belangen te verdedigen. ${ }^{70}$

Het verschil tussen enerzijds de advocaat van de rechtspersoon en anderzijds de lasthebber ad hoc over die rechtspersoon, dat de wetgever door een andere terminologie had willen duidelijk maken (zie hierboven, nr. I9), is hiermee reeds van de baan: de lasthebber ad hoc zal een advocaat zijn, of zich tot een advocaat wenden, om de verdediging van de rechtspersoon te verzekeren zonder geplaagd te zijn door tegenstrijdige belangen. Is dat nu niet precies de taak van de advocaat van de rechtspersoon?

22. Recent heeft het Grondwettelijk Hof een tweede gelegenheid gehad zich over het statuut van de lasthebber ad hoc uit te spreken. Aanleiding was de (eerder banale) kwestie van de erelonen van de lasthebber ad hoc: wat in geval de rechtspersoon over wie hij als lasthebber ad hoc werd aangesteld, onvermogend blijkt te zijn of in de loop van de procedure onvermogend wordt? Over de erelonen van de lasthebber

70 Arbitragehof, arrest nr. I90/2006 van 5 december 2006, overweging B.9. 
ad hoc is overigens heel wat te doen geweest, maar die discussie ${ }^{71}$ is in het kader van dit preadvies van minder belang. ${ }^{72}$

In elk geval, aan het Grondwettelijk Hof werd de ongelijke behandeling van de lasthebber ad hoc t.o.v. de curator voorgelegd: deze laatste beschikt immers over het voorrecht van de gerechtskosten, ${ }^{73}$ over de mogelijkheid van kosteloze rechtspleging ${ }^{74}$ en ten slotte, als het actief van een faillissement ontoereikend is, kunnen de erelonen van de curator worden begroot ten laste van de staat. Voor de schuldbemiddelaar gelden gelijkaardige bepalingen. Voor de lasthebber ad hoc daarentegen bestaat geen gelijkaardig mechanisme dat hem de betaling van zijn erelonen waarborgt, wanneer de rechtspersoon die hij vertegenwoordigt in gebreke blijft.

Deze ongelijke behandeling is in de ogen van het Grondwettelijk Hof evenwel niet onredelijk, en wel om volgende reden:

'De curator of de schuldbemiddelaar houdt niet alleen rekening met de belangen van de gefailleerde of van de schuldenaar die schuldbemiddeling heeft genoten, maar met name ook met de belangen van de gezamenlijke schuldeisers. Bovendien wordt de uitoefening van de functie van curator en van schuldbemiddelaar aan voorwaarden inzake beroepsbekwaamheid onderworpen. Hun activiteit wordt eveneens onderworpen aan een rechterlijke controle en hun erelonen maken het voorwerp uit van een bij koninklijk besluit vastgesteld barema.

Die kenmerken onderscheiden de faillissementscurator en de schuldbemiddelaar van de lasthebber ad hoc, die niet aan vooraf bepaalde voorwaarden inzake beroepsbekwaamheid moet voldoen, enkel de belangen van de vervolgde rechtspersoon vertegenwoordigt, geen verantwoording moet afleggen aan de rechter die hem heeft aangewezen en zijn erelonen vrij bepaalt. ${ }^{7}$

Aan wat doet dat denken: iemand die de belangen van de vervolgde rechtspersoon vertegenwoordigt, die geen verantwoording moet afleggen aan de rechter, die vrij zijn erelonen bepaalt (en, zullen sommigen met een knipoog hieraan toevoegen, die niet hoeft te voldoen aan bepaalde voorwaarden inzake beroepsbekwaamheid)? Aan een advocaat van de vervolgde rechtspersoon, met dat ene fundamentele verschil dat deze laatste niet door de rechter wordt aangewezen.

\section{I.I.4.2 Lering uit de rechtspraak van het Hof van Cassatie}

23. Een advocaat was tijdens de procedure in eerste aanleg aangewezen als lasthebber ad hoc van een rechtspersoon. In beroep oordeelden de appelrechters dat

7I Bv. over de vraag wie de erelonen mag begroten (de rechter of de lasthebber ad hoc zelf), of het om gerechtskosten gaat dan wel over verdedigingskosten die door de rechtspersoon moeten worden betaald, ook in geval de rechtspersoon wordt vrijgesproken ...

72 Zie o.m. J. CASTIAUX, 'Les honoraires du mandataire ad hoc', Dr.pén.entr. 20Io, 5 e.v.

73 Artikel I7 van de Hypotheekwet van I6 december I85I (BS 22 december I85I): 'De gerechtskosten zijn bevoorrecht op de roerende en de onroerende goederen, ten aanzien van alle schuldeisers in wier belang zij zijn gemaakt.'

74 Artikel 666, ${ }^{\text {ste }}$ lid van het Gerechtelijk Wetboek: 'Wanneer vermoed wordt dat het actief van een faillissement ontoereikend zal zijn om de eerste vereffeningskosten te dekken, beveelt de rechter voor wie de zaak aanhangig is, a mbtshalve of op verzoek van de curator de kosteloze rechtspleging.'

75 Grondwettelijk Hof, arrest nr. 85/20I5 van II juni 20I5, overweging B.6.3. 
de aanstelling van een lasthebber ad hoc zich niet (langer) opdringt, waarop ze de rechtspersoon tot een geldboete veroordeelden.

Tegen dit arrest werd cassatieberoep aangetekend door de in eerste aanleg aangewezen lasthebber ad hoc (!). Met arrest van 7 januari 2003 werd het bestreden arrest van het hof van beroep door het Hof van Cassatie vernietigd, daar uit de stukken waarop het vermocht acht te slaan niet bleek dat de betrokken advocaat in zijn hoedanigheid van lasthebber ad hoc werd opgeroepen en gehoord, hetgeen een miskenning inhoudt van zijn recht van verdediging ... m.a.w. van de rechten van verdediging van de lasthebber ad hoc. ${ }^{76}$

24. In een arrest van 26 september 2006 oordeelde het Hof van Cassatie dat wanneer de rechtbank een lasthebber ad hoc heeft aangewezen om de rechtspersoon te vertegenwoordigen, uitsluitend deze lasthebber ad hoc bevoegd is om namens de rechtspersoon rechtsmiddelen, met inbegrip van het cassatieberoep, aan te wenden tegen de beslissingen over de strafvordering t.a.v. de rechtspersoon. Het cassatieberoep was aangetekend door de advocaat van de rechtspersoon en niet door de lasthebber ad hoc. Daar niet bleek dat de advocaat van de rechtspersoon het cassatieberoep had aangetekend namens de lasthebber ad hoc, werd het cassatieberoep afgewezen als niet ontvankelijk. ${ }^{77}$

Dit arrest werd nadien reeds meerdere malen bevestigd. $7^{8}$

In het arrest van het Hof van Cassatie van 9 juni 2009 werd het cassatieberoep dat voor en namens een rechtspersoon was aangetekend door twee natuurlijke personen, die bevoegd waren om de rechtspersoon te vertegenwoordigen, niet ontvankelijk verklaard daar de correctionele rechtbank een lasthebber ad hoc had aangewezen. ${ }^{79}$

En in het arrest van het Hof van Cassatie van 9 februari $201 \mathrm{I}$ werd het cassatieberoep dat voor en namens de rechtspersoon was aangetekend door de raadsman van de rechtspersoon niet ontvankelijk verklaard, daar deze advocaat optrad in naam van de rechtspersoon en niet in naam van de lasthebber ad hoc. ${ }^{80}$

In een recent arrest van 23 juni 2015 heeft het Hof van Cassatie een verder logisch gevolg uit genoemde rechtspraak getrokken: uit artikel 2 bis V.T.Sv.

'volgt niet alleen dat de aangestelde lasthebber ad hoc als enige bevoegd is om namens de rechtspersoon te beslissen over het aanwenden van rechtsmiddelen, maar ook dat de betekening van een cassatieberoep aan een rechtspersoon voor wie een lasthebber ad hoc is aangesteld, slechts regelmatig is als die betekening gebeurde aan deze lasthebber ad hoc. ${ }^{81}$

76 Cass. 7 januari 2003, AR P.02.027I.N.

77 Cass. 26 september 2006, AR P.05.I663.N.

78 Laatst door Cass. 22 mei 20I2, AR P.II.I808.N en Cass. 23 juni 20I5, AR P.I4.0582.N.

79 Cass. 9 juni 2009, AR P.09.0446.N.

80 Cass. 9 februari 20II, AR P.Io.I6I6.F.

8 I Cass., 23 juni 20I5, AR P.I4.0582.N. 
De partij die cassatieberoep instelt, moet het cassatieberoep betekenen aan de partij of de partijen tegen wie het gericht is (art. $427, \mathrm{I}^{\text {ste }}$ lid, $\mathrm{I}^{\text {ste }}$ zin Sv ${ }^{82}$ ). De betekening van het cassatieberoep aan de rechtspersoon zelf - die toch de partij was in het geding - leidt evenwel tot de niet-ontvankelijkheid van het cassatieberoep: er moet betekend worden aan de lasthebber ad hoc.

25. In een zaak die aanleiding gaf tot het arrest van het Hof van Cassatie van 4 oktober 20 II werd een memorie neergelegd, namens zowel de natuurlijke persoon als de rechtspersoon voor wie een lasthebber ad hoc was aangesteld, door één en dezelfde advocaat.

De memorie werd door het Hof van Cassatie, in zoverre ze was neergelegd namens de rechtspersoon, niet ontvankelijk verklaard daar er een lasthebber ad hoc werd aangesteld en daar niet bleek dat de advocaat die de memorie had ingediend, door de lasthebber ad hoc was aangesteld. Tot zover sluit dit arrest enkel aan bij de in het vorige randnummer besproken rechtspraak.

Opmerkelijk zijn evenwel in dat arrest van 4 oktober 20 II de volgende overwegingen van het Hof van Cassatie:

'Deze bepaling [bedoeld wordt: art. 2bis V.T.Sv.] heeft tot doel om, ingeval van gelijktijdige vervolging van een rechtspersoon en van de natuurlijke persoon die bevoegd is om hem te vertegenwoordigen, een onafhankelijke verdediging van de rechtspersoon te waarborgen door de aanstelling van een lasthebber ad hoc.

De lasthebber ad hoc kiest vrij de raadsman van de rechtspersoon. Hij kan, zo hij oordeelt dat er geen gevaar is voor tegenstrijdigheid van belangen, een beroep doen op dezelfde advocaat als de natuurlijke persoon die de rechtspersoon vertegenwoordigt. ${ }^{183}$

De lasthebber ad hoc is dus de enige die een raadsman voor de rechtspersoon kan kiezen. De (raad van bestuur van) de rechtspersoon zelf wordt van dit fundamenteel recht van verdediging verstoken.

\section{I.I.4.3 Besluit}

26. Uit bovenstaande rechtspraak van de hoogste rechtscolleges kan maar één conclusie getrokken worden. De rol van de lasthebber ad hoc overstijgt deze van vertegenwoordiging. Meer dan de rechtspersoon te vertegenwoordigen, komt de lasthebber ad hoc in de plaats van de rechtspersoon, is hij het alter ego van de rechtspersoon, meer nog: is hij de rechtspersoon.

a) De rechten van verdediging van de lasthebber ad hoc komen in de plaats van die van de rechtspersoon.

82 Zoals gewijzigd door de wet van $\mathrm{I}_{4}$ februari $20 \mathrm{I}_{4}$ met betrekking tot de rechtspleging voor het Hof van Cassatie in strafzaken (BS 27 februari 20I4), grotendeels in werking getreden op I februari 2015.

83 Cass. 4 oktober 20II, AR P.Ir.0203.N. 
In de zaak die aanleiding gaf tot het arrest van het Hof van Cassatie van 7 januari 2003 (zie hierboven, nr. 23) was de rechtspersoon immers voor het hof van beroep vertegenwoordigd door een zelf gekozen raadsman. Dat mocht evenwel niet baten: de in eerste aanleg aangeduide lasthebber ad hoc, wiens aanstelling zich volgens de appelrechters niet verder opdrong, was niet opgeroepen en dus waren zijn rechten van verdediging geschonden.

Dat kan alleen maar kloppen als men aanneemt dat de rechtspersoon is vervangen door de lasthebber ad hoc, zodat de schending van de rechten van verdediging van de lasthebber ad hoc gelijkstaat met de schending van de rechten van verdediging van de rechtspersoon. ${ }^{84}$

b) Ook op het vlak van de rechtsmiddelen is deze indeplaatsstelling een feit (zie hierboven, nr. 24).

Aan de ene kant is enkel de lasthebber ad hoc nog bevoegd om rechtsmiddelen aan te wenden tegen de gerechtelijke beslissing t.a.v. de rechtspersoon. In de rechtspraak desbetreffend is trouwens een niet onbelangrijke evolutie waar te nemen. Tot en met het arrest van het Hof van Cassatie van 22 mei 2012 luidde het, dat enkel de lasthebber ad hoc rechtsmiddelen kan aanwenden. In het arrest van 23 juni 2015 heet het onomwonden, dat de lasthebber ad hoc de enige is die over het aanwenden van rechtsmiddelen kan beslissen. ${ }^{85}$

Dat de lasthebber ad hoc de enige is die over rechtsmiddelen kan beslissen, kan alleen maar kloppen als men aanneemt dat de rechtspersoon is vervangen door de lasthebber ad hoc, zodat zijn beslissingen gelijkstaan met die van de rechtspersoon.

Aan de andere kant moeten het openbaar ministerie en de burgerlijke partij hun cassatieberoep betekenen aan de lasthebber ad hoc, op straffe van niet-ontvankelijkheid. Dat de betekening van het cassatieberoep aan de rechtspersoon zelf - toch de partij in zake - niet geldig is, maar enkel die aan de lasthebber ad hoc, kan alleen maar kloppen als men aanneemt dat de rechtspersoon vervangen is door de lasthebber ad hoc, zodat betekeningen aan hem gelijkstaan met die van de rechtspersoon.

c) De lasthebber ad hoc is tenslotte de enige die de raadsman van de rechtspersoon kan aanstellen (zie hierboven, nr. 25) en die dus zelf een raadsman kan kiezen.

84 J. DU JARDIN merkt over dit arrest zeer raak op dat uit het feit dat het Hof het cassatieberoep van de lasthebber ad hoc ontvankelijk heeft verklaard, volgt dat het Hof het bestreden arrest niet beschouwt als een arrest dat t.a.v. de lasthebber ad hoc bij verstek werd gewezen: 'Het recht van verdediging in de rechtspraak van het Hof van Cassatie (1990-2003), Plechtige openingsrede I september 2003, RW 2003-04, 779 .

85 Dat zat wellicht al vervat in de vroegere formulering: als de lasthebber ad hoc de enige is die een rechtsmiddel mag aanwenden, dan mag de raad van bestuur van de rechtspersoon beslissen wat hij maar wil m.b.t. het aantekenen van hoger beroep, want als de lasthebber ad hoc dat beroep niet aantekent, dan kan het niet - toch niet op een ontvankelijke manier - aangetekend worden. Niettemin expliciteert de formulering in het arrest van 23 juni 2015 één en ander bijzonder duidelijk voor de eventuele moeilijke verstaander. 
De raadsman die voorheen (door de raad van bestuur) als advocaat van de rechtspersoon was aangesteld, verliest door de aanstelling van de lasthebber ad hoc m.a.w. zijn mandaat: hij mag niet meer pleiten, geen conclusie meer neerleggen, geen hoger beroep meer aantekenen. Hij is dus niet langer de advocaat van de rechtspersoon.

Dat kan opnieuw alleen maar kloppen als men aanneemt dat de rechtspersoon vervangen is door de lasthebber ad hoc: immers alleen de partij - en het is toch de rechtspersoon die wordt vervolgd, niet de lasthebber ad hoc - kan zijn raadsman de laan uitsturen.

Aan dat verlies van mandaat kan overigens wel op twee manieren worden verholpen.

Ofwel kan de lasthebber ad hoc het mandaat van de raadsman van de rechtspersoon hernieuwen. Dat gebeurt in de praktijk wel eens, maar minstens even zo vaak niet. De raadsman van de rechtspersoon is in voorkomend geval dan eigenlijk de raadsman van de lasthebber ad hoc, maar vermits die toch de rechtspersoon is ...

Ofwel duidt de rechter de voorheen door de rechtspersoon gemandateerde raadsman als lasthebber ad hoc aan. Ook dat is al wel eens gebeurd in de praktijk. Daarmee is de kwadratuur van de cirkel een feit. Immers: aan een advocaat die ter zitting verschijnt, in toga en als raadsman van de rechtspersoon, wordt meegedeeld dat er een mogelijk belangenconflict is met de natuurlijke persoon die de rechtspersoon kan vertegenwoordigen en die samen met de rechtspersoon wordt vervolgd. Dat belangenconflict kan maar worden opgelost door de aanstelling van de lasthebber ad hoc. Door nu de raadsman van de rechtspersoon aan te stellen als lasthebber ad hoc is iedereen tevreden: de betrokken advocaat kan verder de belangen van zijn cliënt verdedigen en - weliswaar zonder toga, want hij is niet langer advocaat pleiten voor zijn cliënt, de rechtbank van zijn kant hoeft de zaak niet in voortzetting stellen om de lasthebber ad hoc toe te laten van het dossier kennis te nemen, want de lasthebber ad hoc kent dat dossier al vanuit zijn vorige leven, als advocaat van de rechtspersoon ... Of hoe een belangenconflict wordt opgelost door een toga te verwijderen, in plaats van er één toe te voegen. ${ }^{86}$

27. Vanuit het oogpunt van de rechten van verdediging werpt deze culminatie van bevoegdheden in handen van de lasthebber ad hoc de meest fundamentele bezwaren op, te meer deze lasthebber ad hoc in de meeste gevallen ambtshalve, zonder enige inspraak van de rechtspersoon, wordt aangesteld door dezelfde strafrechter als deze die zich over de vervolgde rechtspersoon zal dienen uit te spreken.

Dat de rechter die zich over de rechtspersoon moet uitspreken op deze manier de door deze rechtspersoon zelf gekozen raadsman opzij kan zetten en aan de rechtspersoon elke inspraak in de verdedigingsstrategie kan ontzeggen, is gewoonweg

86 Zie F. DERUYCK, 'Het is lastig te pleiten zonder toga. Over het onhoudbare artikel 2bis V.T.Sv.', NC $2013,89$. 
onaanvaardbaar. Dat het in de praktijk niet altijd zo ver hoeft te komen - omdat de lasthebber ad hoc zich in de meeste gevallen laat instrueren door de (overige leden van de) raad van bestuur van de vennootschap, omdat hij de door de rechtspersoon gekozen raadsman opnieuw mandateert als zijn raadsman of omdat de rechter de gekozen raadsman van de rechtspersoon aanduidt als lasthebber ad hoc - doet niets af aan deze kritiek. Als de lasthebber ad hoc zijn eigen gang wil gaan, kan hij dat, en als hij dat doet - en ook dat gebeurt in de praktijk - is hij aan niemand verantwoording verschuldigd.

Het is niet voor niets dat in een recent vonnis van de correctionele rechtbank te Luik werd geoordeeld dat de lasthebber ad hoc een sui generis-statuut heeft, wat betekent dat hij geen verantwoording moet afleggen van zijn mandaat. ${ }^{87}$ Wanneer de jurist naar deze Latijnse woorden grijpt, dan verbloemt hij dat wat hij beschrijft - letterlijk vertaald - iets 'eigenaardigs' is, dat hij niet kan plaatsen en eigenlijk niet begrijpt ...

28. Ik heb het in de praktijk al zien gebeuren dat de advocaat van een rechtspersoon een - uiteraard door die rechtspersoon goedgekeurde - conclusie opstelt met de bedoeling deze ter zitting neer te leggen, dan op de zitting wordt geconfronteerd met de aanstelling van een lasthebber ad hoc over zijn cliënte en met een voortzetting van de zaak op een latere datum, om vervolgens te moeten vaststellen dat die lasthebber ad hoc weigert de raadsman van de rechtspersoon 'opnieuw' aan te stellen en evenzeer weigert de voorheen door de rechtspersoon goedgekeurde conclusie neer te leggen.

Ik hoop in de praktijk niet te moeten zien gebeuren dat de niet-vervolgde bestuurders van een vennootschap van oordeel zijn dat hoger beroep moet worden aangetekend tegen een beslissing, maar dat de lasthebber ad hoc, met beroep op de rechtspraak van het Hof van Cassatie, repliceert dat zij niets te willen hebben en dat hij integendeel van oordeel is dat best in de beslissing wordt berust.

De rechtspersoon over wie een lasthebber ad hoc wordt aangesteld, bevindt zich a.h.w. in een toestand van curatele: hij is onbekwaam geworden. Maar men wordt toch niet onbekwaam omdat men vervolgd wordt?

29. Het is hoogtijd deze uitwassen van een ongetwijfeld goedbedoeld wetsartikel een halt toe te roepen.

Dit is a fortiori het geval indien men het standpunt zou volgen dat de aanstelling van een lasthebber ad hoc verplicht is, van zodra een rechtspersoon wordt vervolgd samen met een natuurlijke persoon die hem kan vertegenwoordigen (zie hierboven, nr. I6 e.v.). Het is in dat opzicht tekenend dat in een arrest van het hof van beroep van Gent van 15 januari 2002 - waarin werd beslist dat er van zulkdanige verplich-

87 Corr. Luik I8 oktober 2013, JLMB 2013, 1758. 
ting geen sprake is - werd beslist geen lasthebber ad hoc aan te stellen, o.m. om volgende reden:

'Het Hof houdt hierbij rekening met de principiële vrijheid met betrekking tot de keuze van de verdediging die een beklaagde, ook wanneer het om een vennootschap gaat, wenst te voeren en met de overige rechten van verdediging. ${ }^{88}$

Of hoe de aanstelling van een lasthebber ad hoc, nochtans bedoeld ter vrijwaring van de belangen van de rechtspersoon, wordt geweigerd omwille van de eerbiediging van de rechten van verdediging van deze rechtspersoon.

Het aanpakken van de uitwassen van artikel 2 bis V.T.Sv. is overigens niet alleen nodig vanuit het perspectief van de rechten van verdediging, maar ook vanuit het gelijkheidsbeginsel.

Inderdaad, de rechtspersoon die alleen vervolgd wordt of samen met een natuurlijke persoon die hem evenwel niet kan vertegenwoordigen, ${ }^{89}$ behoudt ten volle de regie van zijn verdediging: keuze van processtrategie, vrije keuze van raadsman, beslissing over het aanwenden van rechtsmiddelen enz.

Enkel de rechtspersoon die de pech heeft te worden vervolgd samen met een natuurlijke persoon die hem kan vertegenwoordigen, wordt volledig opzij geschoven: hij wordt vervangen door een lasthebber ad hoc, die vanaf zijn aanstelling de enige is die de meest fundamentele beslissingen voor de rechtspersoon in het kader van de strafprocedure kan nemen. De rechtspersoon zelf kan dan nog enkel vanuit de coulissen - lees: via de door hem gemandateerde raadsman, die vanop de publieke banken de zitting volgt maar niet mag tussenkomen - volgen wat er met zijn zaak gebeurt. Het blijft immers de zaak van de rechtspersoon, want als er op het einde van de rit een geldboete wordt opgelegd, wordt de vervanging van de rechtspersoon door de lasthebber ad hoc weer tenietgedaan: de boete zal moeten worden betaald door de rechtspersoon, niet door de lasthebber ad hoc.

30. Ik heb eerder al betoogd dat de oplossing niet ligt in het sleutelen aan artikel 2bis V.T.Sv., maar wel in de afschaffing ervan..$^{\circ}$ Mogelijke belangenconflicten tussen verschillende beklaagden dienen niet door de strafrechter te worden opgelost. In de aanname dat dat wel zo is, schuilt m.i. de fout in de hele redenering.

Eventuele belangenconflicten tussen de rechtspersoon en de natuurlijke persoon tijdens het vooronderzoek hebben niet tot gevolg dat het grondig onderzoek van de feiten daardoor zou worden gedwarsboomd. Door het onderzoek naar de feiten zal blijken aan wie ze wel, en aan wie niet, kunnen worden toegerekend.

88 Gent I5 januari 2002, NJW 2002, 63.

89 Verslag namens de Kamercommissie voor Justitie, Parl. St., Kamer, I998-99, nr. 2093/5, p. 42. Zie Luik 9 februari 20I2, JLMB 20I2, I53I: als de beklaagde natuurlijke persoon niet meer bevoegd is om de medebeklaagde rechtspersoon te vertegenwoordigen op het ogenblik dat de strafvordering aanhangig gemaakt wordt bij de rechtbank, dient er geen lasthebber ad hoc te worden aangesteld.

90 F. DERUYCK, 'Het is lastig te pleiten zonder toga. Over het onhoudbare artikel 2bis V.T.Sv.', NC 20I3, 96-97. 
Tijdens dat onderzoek kan de natuurlijke persoon die de rechtspersoon kan vertegenwoordigen en die zelf ook verdacht wordt, uiteraard worden ondervraagd. Wanneer deze natuurlijke persoon dan uitspraken doet namens of over de rechtspersoon, zal vanzelfsprekend een verscherpte waakzaamheid vereist zijn bij de beoordeling van de geloofwaardigheid van deze verklaringen. Dat is hier trouwens niet anders dan in alle andere gevallen, waarin meerdere personen worden verdacht of vervolgd.

Bovendien kunnen naast deze natuurlijke persoon die zelf ook wordt verdacht nog andere personen worden ondervraagd m.b.t. de handelingen, het beleid of de beslissingen van de rechtspersoon. Dat kunnen personen van binnen de rechtspersoon zijn (zie evenwel hierna, onder II), maar mogelijk ook zgn. buitenstaanders, die over de feiten die aan de rechtspersoon worden ten laste gelegd verklaringen kunnen afleggen.

Tenslotte wordt de waarheid niet alleen aan het licht gebracht door personen te ondervragen, maar ook door andere daden van onderzoek, zoals bv. de huiszoeking en de inbeslagname van documenten. In het kader van onderzoeken naar economische of financiële misdrijven - het soort zaken waarin vaak rechtspersonen opduiken - is het resultaat van dergelijke daden van onderzoek overigens vaak veel doorslaggevender dan gelijk welke verklaring.

Eventuele belangenconflicten tussen de rechtspersoon en de natuurlijke persoon voor de hoven en rechtbanken moeten in eerste instantie worden beoordeeld door de partijen zelf en door de individuele advocaat of advocaten, die door die partijen worden belast met hun verdediging. De deontologie van de advocaat verbiedt hem tegenstrijdige belangen te verdedigen en verplicht hem om de belangen van zijn cliënt - of van zijn cliënten - naar best vermogen te verdedigen.

In het reeds geciteerde arrest van I5 januari 2002 van het hof van beroep te Gent (zie hierboven, nr. 29) werd de weigering een lasthebber ad hoc aan te duiden verder gemotiveerd als volgt:

'Verder houdt het Hof rekening met het feit dat voor de beide beklaagden dezelfde raadsman optreedt, die, hierover door het Hof geïnterpelleerd, oordeelt dat ter zake geen sprake is van strijdigheid van belangen. Ofschoon dit gegeven op zichzelf niet steeds doorslaggevend hoeft te zijn, is het toch een belangrijk element in acht genomen de regels van de beroepsdeontologie die de advocaat, behoudens ter zake niet blijkende tegenaanwijzingen, geacht wordt na te leven. ${ }^{9}$

Men zou nog een discussie kunnen openen over de vraag of, wanneer een advocaat ter zitting voor twee partijen verschijnt, hij hierdoor niet aangeeft dat er geen belangenconflict tussen zijn cliënten is en daarover dan ook niet meer door de rechter 'geïnterpelleerd' hoeft te worden, maar dergelijke kleinzerigheden doen hier verder niet ter zake. Wat telt is dat belangenconflicten tussen beklaagden niet moeten worden opgevangen door de rechter, maar wel door de partijen zelf en hun respectieve advocaten.

9I Nogmaals Gent I5 januari 2002, NJW 2002, 63. 
Dat is zo voor natuurlijke personen, en - het bovenstaande antropomorfisme (zie hierboven, nr. 2) indachtig - dat zou dus ook zo moeten zijn voor de rechtspersoon.

De eerbiediging van de rechten van verdediging van de rechtspersoon gebiedt m.i. dan ook de afschaffing van artikel 2 bis V.T.Sv. ${ }^{22}$

3I. Men hoort tenslotte wel eens, a.h.w. als laatste argument, dat een lasthebber ad hoc zich niettemin minstens in één geval opdringt, met name wanneer het doen en laten van de rechtspersoon (nagenoeg) volledig wordt bepaald door één natuurlijke persoon, die samen met de rechtspersoon vervolgd wordt. Men denke aan een besloten vennootschap met beperkte aansprakelijkheid met één aandeelhouder, die dus de totaliteit van de aandelen bezit en die daarnaast ook de zaakvoerder van deze vennootschap is (een zgn. eenmans-bvba). Indien in zo'n geval de 'rechtspersoon' een advocaat mandateert, zal dat in feite die ene natuurlijke persoon zijn met wie de raadsman van de rechtspersoon dan overleg zal moeten plegen en van wie hij zijn instructies zal krijgen. In zo'n geval zou dan, om de onafhankelijke verdediging van de rechtspersoon te vrijwaren, toch een lasthebber ad hoc over de rechtspersoon moeten worden aangeduid, die zich onafhankelijk van deze allesbepalende natuurlijke persoon kan opstellen.

Het gaat m.i. evenwel om een valse hypothese. Indien er in werkelijkheid geen onderscheid gemaakt kan worden tussen de allesbepalende natuurlijke persoon en de rechtspersoon, heeft de vervolging van de rechtspersoon eigenlijk weinig zin. Als de rechtspersoon volledig bestierd en bestuurd wordt door één en dezelfde natuurlijke persoon met wie die rechtspersoon samen wordt vervolgd, dan is die rechtspersoon eigenlijk geen dader, maar louter een instrument van de natuurlijke persoon. Als alle beslissingen van de rechtspersoon genomen worden door één en dezelfde natuurlijke persoon, hoe kan die rechtspersoon dan een zelfstandig verwijt gemaakt worden? Die rechtspersoon kon dan toch niet anders handelen dan hij door sturing van die ene natuurlijke persoon heeft gehandeld?

In een recent arrest van het Hof van Cassatie van 3 maart 2015 werd nochtans geoordeeld dat in hoofde van een eenmans-bvba wel degelijk een eigen schuldpatroon kan worden vastgesteld: de omstandigheid dat voor het doen van die vaststelling rekening wordt gehouden met de gedragingen of verzuimen van de enige vennoot of zaakvoerder belet zulks niet. ${ }^{33}$ Maar met wat zou in dergelijke hypothese anders rekening kunnen gehouden worden, dan met de gedragingen of verzuimen van die enige vennoot of zaakvoerder? In het bestreden arrest was overwogen dat de rechtspersoon niets heeft ondernomen om een einde te stellen aan de misdrijven. Maar hoe zou de

92 Anders: P. WAETERINCKX, 'De (afgeleide) rechten van verdediging van de rechtspersoon. Heeft een rechtspersoon het recht te zwijgen, eventueel met of zonder bijstand van een raadsman?', NC 2015, 82-83. Deze auteur ziet meer heil in het opwaarderen van de rol van het verzoekschrift tot aanstelling van een lasthebber ad hoc, uitgaande van de rechtspersoon zelf. Maar ook dan 'verdwijnt' de rechtspersoon a.h.w. als zelfstandige procespartij, eens die lasthebber ad hoc is aangesteld. Dat blijft m.i. nefast, ook al werd de lasthebber ad hoc voorgedragen door de rechtspersoon.

Cass. 3 maart 20I5, AR P.I3.I26I.N, T.Strafr. 20I5, 80, noot B. MEGANCK. 
rechtspersoon dat kunnen, als er maar één vennoot of zaakvoerder is die alles beslist? Hoe kan de bvba Jan Janssens zich verzetten tegen de misdrijven die worden gepleegd door haar enige zaakvoerder en aandeelhouder, de Heer Jan Janssens?

In een goedkeurende noot bij het arrest van 3 maart 2015 wordt het standpunt dat rechtspersonen niet strafrechtelijk verantwoordelijk kunnen worden gesteld wanneer er geen ruimte is om een eigen, van de leidinggevende natuurlijke persoon afwijkende, koers te varen, afgewezen als indruisend tegen de basisidee van de wet van 4 mei 1999, met name het zoveel mogelijk gelijkschakelen van natuurlijke persoon en rechtspersoon ${ }^{94}$ (zie hierboven, nr. 2).

In plaats van tegen die basisidee in te druisen, komt dergelijke stelling m.i. integendeel met die basisidee overeen. Als een natuurlijke persoon een derde (ook natuurlijke persoon) als louter instrument gebruikt om een misdrijf te doen plegen, is hij de uitvoerder van het misdrijf en niet de aanzetter ervan: hij bedient zich immers van die andere persoon, die niet weet dat hij aan een misdrijf deel heeft, ${ }^{95}$ zodat die andere persoon vrijuit gaat. Waarom zou dat anders zijn wanneer een natuurlijke persoon zich bedient van een rechtspersoon als louter instrument om een misdrijf te (doen) plegen?

De nood aan de invoering van de strafrechtelijke verantwoordelijkheid van rechtspersonen was ingegeven door de moeilijkheid, het door de rechtspersoon gepleegde misdrijf toe te rekenen aan één of meer welbepaalde natuurlijke personen, zoals nochtans in het oude recht van vóór de wet van 4 mei 1999 vereist was. ${ }^{96} \mathrm{Bij}$ eenmansvennootschappen is die toerekening evenwel om evidente redenen niet problematisch. De strafrechtelijke verantwoordelijkheid van rechtspersonen is er om straffeloosheid te voorkomen, niet om naast een natuurlijke persoon ook nog eens een - vanuit penaal oogpunt, meer bepaald vanuit het oogpunt van verwijtbaarheid - niet van hem te onderscheiden rechtspersoon te kunnen vervolgen en bestraffen.

Ofwel heeft men te maken met een rechtspersoon die niet volledig afhangt van de handelingen en verzuimen van één welbepaalde natuurlijke persoon. Dan kan de

94 B. MEGANCK, 'Strafrechtelijke veran twoordelijkheid eenmansvennootschap: het eigen schuldpatroon van de rechtspersoon' (noot onder Cass. 3 maart 2015), RABG 2015, 83-84, nr. 9.

95 A. DE NAUW en F. DERUYCK, Overzicht van het Belgisch algemeen strafrecht, Brugge, die Keure, 2015, 92, nr. 207, met verwijzing naar Cass. 9 maart I993, Arr. Cass. I993, nr. I33. Zie recent ook Cass. 22 januari 2013, AR P.12.0625.N.

96 Volgens de rechtspraak van het Hof van Cassatie van vóór de wet van 4 mei 1999 konden rechtspersonen wel misdrijven plegen, maar er niet voor gestraft worden. De strafrechtelijke verantwoordelijkheid voor het door de rechtspersoon gepleegde misdrijf rustte integendeel op de natuurlijke persoon, die het misdrijf in concreto voor de rechtspersoon had gepleegd. Deze natuurlijke persoon diende daarbij uiteraard zélf een persoonlijke fout te hebben begaan (standvastige rechtspraak vanaf het arrest van II december 1967, AC I968, 524; zie hierover A. DE NAUW, 'La délinquance des personnes morales et l'attribution de l'infraction à une personne physique par le juge', RCJB I992, 552 e.v.). De toerekening van het door de rechtspersoon gepleegde misdrijf aan een welbepaalde natuurlijke persoon leverde in de rechtspraktijk evenwel tal van bewijsproblemen op, vooral wanneer het gaat om moderne vennootschappen, gekenmerkt door een wirwar van zowel horizontaal als verticaal verdeelde bevoegdheden, door delegatie en decentralisatie en door collegiaal genomen beslissingen. Dat leidde vaak tot vrijspraken en dus tot straffeloosheid (zie hierover uitvoering F. DERUYCK, De rechtspersoon in het strafrecht, Gent, Mys \& Breesch, I996, i.h.b. 13-43). 
raadsman van de rechtspersoon overleg plegen met en instructies bekomen van de rechtspersoon via andere natuurlijke personen, bv. via de niet vervolgde bestuurders van de rechtspersoon.

Ofwel heeft men te maken met een rechtspersoon die bestuurd wordt door één allesbepalende natuurlijke persoon (zaakvoerder en roo \% aandeelhouder). Zo'n rechtspersoon is m.i. geen dader van een misdrijf, maar louter instrument in handen van die natuurlijke persoon bij het plegen van dat misdrijf. Het heeft m.i. dan ook geen zin dergelijke rechtspersoon strafrechtelijk te vervolgen. Maar als hij toch vervolgd wordt, wat in de praktijk inderdaad vaak gebeurt, wat voor zin heeft het dan er een lasthebber ad hoc over aan te stellen? Ook die lasthebber ad hoc heeft, net zoals de raadsman van de rechtspersoon, geen enkel ander aanspreekpunt dan die ene natuurlijke persoon. Hij kan toch niet de verdediging van de rechtspersoon volledig in het abstracte, in het luchtledige opbouwen?

De kwestie van de eenmansvennootschappen is er m.i. één van materieel strafrecht. Ze is niet van aard bovenstaand principieel standpunt m.b.t. de afschaffing van de lasthebber ad hoc te ondermijnen.

\section{I.2 De verschijning van de rechtspersoon overeenkomstig de artikelen I52 en $185 \mathrm{~Sv}$.}

32. Om meteen met de deur in huis te vallen: de wetgever heeft - uiteindelij $\mathrm{k}^{97}-$ geen afwijkende bepaling m.b.t. de verschijning van de rechtspersoon voor de feitenrechter ingevoerd. De desbetreffende bepalingen gelden derhalve in principe gelijkelijk voor natuurlijke personen en rechtspersonen.

Die bepalingen houden in dat de beklaagde voor de politierechtbank (art. I52, § I Sv.) of voor de correctionele rechtbank (art. I85, § I Sv.) ofwel persoonlijk verschijnt, ofwel in de persoon van een advocaat. De beschuldigde voor het hof van assisen moet steeds persoonlijk verschijnen, vertegenwoordiging door een advocaat is daar niet toegestaan (art. 254, $\mathrm{I}^{\text {ste }} \mathrm{lid} \mathrm{Sv} .{ }^{9^{8}}$ ).

97 Na de wet van 4 mei 1999 was er immers wel degelijk nog een verschil, wat de verschijning betreft, tussen natuurlijke personen en rechtspersonen. Natuurlijke personen dienden namelijk in bepaalde gevallen in persoon te verschijnen (voor de politierechtbank was de regel dat ze persoonlijk of in de persoon van een advocaat konden verschijnen, behalve in een aantal uitzonderingsgevallen waarin ze persoonlijk moesten verschijnen, voor de correctionele rechtbank was de regel dat ze in persoon moesten verschijnen, behalve in een aantal uitzonderingsgevallen waarin ze ook in de persoon van een advocaat konden verschijnen: artikelen 152 resp. I85 oud Sv.).

Het vereiste van persoonlijke verschijning van de natuurlijke persoon werd evenwel verlaten ingevolge rechtspraak van het EHRM (zie de wet van I2 februari 2003 tot wijziging van het Wetboek van Strafvordering wat het verstek betreft en tot opheffing van artikel 42I van hetzelfde Wetboek, BS 28 maart 2003). Na deze wet was er geen enkel verschil meer tussen de regels van verschijning voor de natuurlijke persoon en deze voor de verschijning van de rechtspersoon.

98 Artikel 254, I $^{\text {ste }}$ lid Sv. bepaalt dat de voorzitter van het hof van assisen ten minste vijftien dagen voorafgaand aan de preliminaire zitting zich er van dient te vergewissen dat de beschuldigde een raadsman heeft gekozen om hem in zijn verdediging bij te staan. Indien dit niet het geval blijkt te zijn, dient de voorzitter hem in overleg met de stafhouder een raadsman toe te voegen, op straffe van nietigheid van alles wat volgt. 
De beklaagde rechtspersoon kan zich dus ofwel ter zitting van de rechtbank laten vertegenwoordigen door zijn raadsman, ofwel persoonlijk verschijnen. In dat laatste geval verschijnt de rechtspersoon, overeenkomstig het vennootschapsrecht, door één van zijn organen. ${ }^{99}$

De politierechtbank (art. 152, § 2 Sv.) of de correctionele rechtbank (art. 185, § 2 Sv.) kan evenwel in elke stand van het geding de persoonlijke verschijning bevelen. Tegen deze beslissing staat geen rechtsmiddel open. Als de persoonlijke verschijning van een rechtspersoon wordt bevolen, zal deze ook hier, overeenkomstig het vennootschapsrecht, één van zijn organen gelasten om hem te vertegenwoordigen. De raadsman van de rechtspersoon kan dan eveneens aanwezig zijn om bijstand te verlenen.

Deze regels worden uiteraard doorkruist indien over de rechtspersoon een lasthebber ad hoc wordt aangesteld. Dan verschijnt de rechtspersoon ofwel persoonlijk, lees: in de persoon van de lasthebber ad hoc ${ }^{100}$ die immers de rechtspersoon vervangt, of in de persoon van een advocaat, lees: een advocaat die door de lasthebber ad hoc werd gemandateerd. Als de persoonlijke verschijning wordt bevolen, dient de lasthebber ad hoc zelf te verschijnen, eens te meer eventueel met bijstand van een door hem gemandateerde raadsman.

33. Vanuit rechtsvergelijkend perspectief is het niet oninteressant te vermelden dat de wetgever een tijdlang overwogen heeft, een gelijkaardige bepaling in te voeren als deze van artikel 528.3 Ned. Sv., naar luid waarvan de rechter de persoonlijke verschijning van een bepaalde bestuurder of vennoot kan bevelen. ${ }^{\text {ior }}$

Inderdaad, in de Senaat werd - overigens zonder verantwoording - een amendement ingediend tot aanvulling van een derde lid aan artikel I85, § 2 Sv. m.b.t. de verschijning voor de correctionele rechtbank. Dat derde lid luidde als volgt:

'Is de beklaagde een rechtspersoon, dan verschijnt hij door een advocaat. De rechter kan evenwel de persoonlijke verschijning bevelen en wijst in dat geval de persoon aan die of het orgaan dat de rechtspersoon moet vertegenwoordigen.' ${ }^{102}$

De tekst van dit amendement werd nadien ingevolge een subamendement nog licht aangepast. De zinsnede 'dan verschijnt hij door een advocaat' werd gewijzigd in

99 Vergelijk vroeger reeds Cass. I2 februari I973, Arr. Cass. I972-73, 590: voor de strafgerechten verschijnt een rechtspersoon in de hoedanigheid van burgerlijke partij hetzij persoonlijk door één van zijn organen, hetzij in de persoon van een advocaat.

Ioo Verslag namens de Senaatscommissie voor Justitie, Parl. St., Senaat, I998-99, nr. I-I2I7/6, p. 83. Tevens verslag namens de Kamercommissie voor Justitie, Parl. St., Kamer, I998-99, nr. 2093/5, p. 42.

IOI De verdere toevoeging in artikel 528.3 Ned.Sv., dat de rechter in dat geval de medebrenging van die bestuurder of vennoot kan gelasten, is daarentegen nooit in het debat gebracht.

I02 Amendement nr. 8 van de Heer BOUTMANS, Parl. St., Senaat, I998-99, nr. I-I2I7/2, p. 4. 
'dan kan hij verschijnen door een advocaat'. ${ }^{103}$ De verplichting voor een vennootschap zich te laten vertegenwoordigen door een advocaat werd m.a.w. afgezwakt tot een mogelijkheid. De vennootschap kan immers ook persoonlijk verschijnen, in welk geval de wet of de statuten bepalen wie in rechte de vertegenwoordigingsbevoegdheid bezit ${ }^{104}$.

Daarop diende de regering een gelijkaardig amendement in tot aanvulling van een derde lid aan artikel I52, § 2 Sv. m.b.t. de verschijning voor de politierechtbank ${ }^{105}$. Voor het hof van assisen was volgens de minister van Justitie een dergelijke regeling niet vereist: daar is de persoonlijke verschijning immers de regel. ${ }^{\mathrm{r} 6}$ In de logica van de voorgaande amendementen valt nochtans niet goed in te zien waarom, wanneer de persoonlijke verschijning door het hof van assisen zelfs niet bevolen dient te worden maar uit de wet voortvloeit, er eigenlijk niet nog meer nood is aan een regeling waarbij het orgaan of de persoon die de rechtspersoon moet vertegenwoordigen, door de rechter wordt aangeduid ...

Hoe dan ook zijn de beschouwingen waartoe de voorgenomen regeling m.b.t. de verschijning voor de politierechtbank en de correctionele rechtbank aanleiding heeft gegeven, op zijn minst opmerkelijk te noemen.

Vooreerst rees de vraag in welke hoedanigheid de door de rechtbank aangewezen persoon zou verschijnen. Het is immers de bedoeling dat de rechter de voor hem verschijnende persoon moet kunnen ondervragen, anders heeft het bevel tot persoonlijke verschijning weinig $\operatorname{zin}^{\text {107 }}$. Verschijnt de aangeduide persoon dan als beklaagde of als getuige en, als het als getuige is, moet deze dan de eed afleggen? Volgens een lid van de Senaatscommissie moet het imperatief in één van die twee hoedanigheden zijn ('een derde weg is niet mogelijk'), volgens een ander lid van de commissie verschijnt de aangewezen persoon noch als getuige, noch als beklaagde. ${ }^{108}$ Volgens de minister van Justitie is die persoon alleen maar de fysieke vertegenwoordiger van de rechtspersoon en is het helemaal niet nodig dat hij bij de feiten betrokken is, ${ }^{109}$ waarbij overigens de vraag rijst of hij wel zou mogen betrokken zijn bij de feiten. Maar waarover kan die persoon dan nuttige verklaringen afleggen?

Voorts werd benadrukt dat deze persoon uiteraard informatie zal moeten inwinnen over de positie van de rechtspersoon t.o.v. de tegen hem ingestelde strafvordering

I03 Amendement nr. 29 van de Heer VANDENBERGHE (subamendement op amendement nr. 8), Parl. St., Senaat, I998-99, nr. I-I2I7/4, p. 4 .

I04 Verslag namens de Senaatscommissie voor Justitie, Parl. St., Senaat, I998-99, nr. I-I2I7/6, p. 82.

I05 Amendement nr. 3I van de regering, Parl. St., Senaat, I998-99, nr. I-I2I/4, p. 5. De indiener van het amendement nr. 8 had namelijk over het hoofd gezien dat rechtspersonen niet enkel voor de correctionele rechtbank kunnen verschijnen, maar ook voor de politierechtbank.

Io6 Verslag namens de Senaatscommissie voor Justitie, Parl. St., Senaat, I998-99, nr. I-I2I7/6, p. 85. Voor het hof van assisen verschijnt de rechtspersoon dus ofwel via een orgaan, ofwel via de aangeduide lasthebber ad hoc.

I07 Verslag namens de Senaatscommissie voor Justitie, Parl. St., Senaat, I998-99, nr. I-I2I7/6, p. 88.

Io8 Verslag namens de Senaatscommissie voor Justitie, Parl. St., Senaat, I998-99, nr. I-I2I7/6, p. 84.

Io9 Verslag namens de Senaatscommissie voor Justitie, Parl. St., Senaat, I998-99, nr. I-I217/6, p. 86. 
en daarover met de rechtspersoon overleg moet plegen. Dat makt deel uit van de interne verantwoordelijkheid van de persoon binnen de organisatie, zo niet zou zijn persoonlijke verantwoordelijkheid in het gedrang kunnen komen. ${ }^{\text {IIO }}$ Maar is het bepalen van de verdedigingspositie, in overleg met de rechtspersoon, nu niet net de taak van de raadsman van de rechtspersoon?

Tenslotte werd - eindelijk - de pertinente vraag gesteld of de regeling, waarbij de rechtbank de persoon aanduidt die voor de rechtspersoon moet verschijnen, wel veel zin heeft:

'Welke legitimiteit tegenover de rechtspersoon bezit iemand die de rechter rechtstreeks heeft aangewezen als vertegenwoordiger?' ${ }^{\mathrm{II}}$

Na nog wat heen en weer gepraat over de rol van de natuurlijke persoon die door de rechtbank zou worden aangeduid om de persoonlijke verschijning van de rechtspersoon te materialiseren (toch weer getuige, maar dan toch weer niet als het om iemand gaat die volgens de wet of de statuten gemachtigd is de rechtspersoon te vertegenwoordigen ...), kwam de minister van Justitie tot het besluit dat de voorgestelde tekst beter zou worden geschrapt. ${ }^{\mathrm{II} 2}$ Via een nieuw amendement ${ }^{\mathrm{II} 3}$ dat uiteindelijk werd goedgekeurd, werd vervolgens als regel aangenomen dat de rechtspersoon ofwel persoonlijk verschijnt, ofwel in de persoon van een advocaat (zie hierboven, nr. 32).

Het valt te betreuren dat de wetgever geen gelijkaardige inzichten heeft gehad m.b.t. de figuur van de lasthebber ad hoc. De zopas geciteerde vraag naar legitimiteit geldt immers ook voor deze door de rechter aangeduide vertegenwoordiger ...

\section{De uitoefening van het zwijgrecht van de rechtspersoon}

34. Het zwijgrecht maakt deel uit van de essentiële rechten van verdediging, zoals gewaarborgd door artikel 6 van het EVRM. ${ }^{114}$ Het behoort tot de kern van het recht op een eerlijk proces, geconsacreerd in het eerste lid van deze bepaling. Zo overwoog het EHRM in de zaak Saunders/Verenigd Koninkrijk:

IIo Verslag namens de Senaatscommissie voor Justitie, Parl. St., Senaat, I998-99, nr. I-I2I7/6, p. 87.

III Verslag namens de Senaatscommissie voor Justitie, Parl. St., Senaat, I998-99, nr. I-I2I7/6, p. 87.

II2 Verslag namens de Senaatscommissie voor Justitie, Parl. St., Senaat, I998-99, nr. I-I2I7/6, p. 88.

II3 Amendement nr. 35 van de Heer ERDMAN, Parl. St., Senaat, I998-99, nr. I-I2I7/4, p. 6.

II4 Zie over de rechten van verdediging, in het algemeen: Les droits de la défense en matière pénale, Luik, Éd. du Jeune Barreau de Liège, I985; F. TULKENS en D. VANDERMEERSCH, 'L'évolution des droits de la défense depuis un siècle', in Cent ans de publication de droit pénal en de criminologie, H. BOSLY, F. DEMANET, J. MESSINE en B. MICHEL (eds.), Brussel, La Charte, 2007, I7I-2I5; R. VERSTRAETEN en $\mathrm{Ph}$. TRAEST, 'Het recht van verdediging in de onderzoeksfase', NC 2008, 85-105; L. HUYBRECHTS en M. ROZIE, 'De rechten van verdediging bij de behandeling ten gronde', NC 2008, I06-I29.

Zie, i.h.b. over het zwijgrecht, J. MEESE, 'The sound of silence. Het zwijgrecht en het nemo teneturbeginsel in strafzaken. Een historisch en rechtsvergelijkend overzicht', in Zwijgrecht versus spreekplicht, J. ROZIE, S. RUTTEN en A. VAN OEVELEN (eds.), Antwerpen-Cambridge, Intersentia, 20I3, 37-72. 
'The Court recalls that, although not specifically mentioned in Article 6 of the Convention, the right to silence and the right not to incriminate oneself are generally recognized international standards which lie at the heart of the notion of a fair procedure under Article 6.'15

Het kan zonder enige twijfel eveneens gekoppeld worden aan het onschuldvermoeden, verwoord in het tweede lid van deze bepaling. Zo overwoog het EHRM in het zojuist geciteerde arrest Saunders verder:

'The right not to incriminate oneself, in particular, presupposes that the prosecution in a criminal case seek to prove their case against the accused without resort to evidence obtained through methods of coercion or oppression in defiance of the will of the accused. In this sense the right is closely linked to the presumption of innocence contained in Article 6 para. 2 of the Convention. ${ }^{116}$

Het zwijgrecht houdt tenslotte inderdaad tevens verband met het recht niet verplicht te kunnen worden zichzelf te incrimineren of mee te werken aan de bewijsvoering tegen zichzelf: Nemo tenetur se ipsum prodere. ${ }^{\text {II }}$

35. Dat de waarborgen van artikel 6 van het EVRM niet enkel voor natuurlijke personen gelden maar ook voor rechtspersonen, kan nog moeilijk worden betwist sinds de Europese Commissie van de Rechten van de Mens in I99I oordeelde dat 'a corporate body can claim the protection of article 6 of the Convention when a criminal charge has been made against ${ }^{\prime}{ }^{\prime \prime 1}{ }^{18}$. Zo erkende het Hof van Beroep te Brussel in de zgn. Citibank-zaak uitdrukkelijk dat rechtspersonen over identieke waarborgen beschikken als natuurlijke personen en dus ook een zwijgrecht hebben. ${ }^{\text {II9 }}$ Dat standpunt wordt ook in de rechtsleer vertolkt. ${ }^{120}$

Hoe evenwel die waarborgen - en inzonderheid het zwijgrecht - in hoofde van een rechtspersoon kunnen worden geconcretiseerd, werd in de Belgische doctrine lange tijd nauwelijks bestudeerd.

Het is de verdienste van S. COISNE en P. WAETERINCKX daartoe een eerste aanzet te hebben gegeven in 2005. ${ }^{\text {I2I }}$ Laatstgenoemde auteur heeft de draad opnieuw

II5 EHRM, arrest Saunders/Verenigd Koninkrijk d.d. I7 december I996, Rep. Eur. Court H.R. I996, VI, 2044, i.h.b. § 68. Zie voorheen reeds EHRM, arrest Funke/Frankrijk d.d. 25 februari I993, Publ. Eur. Court H.R. I993, Serie A, nr. 256-A, i.h.b. § 44 en EHRM, arrest Murray/Verenigd Koninkrijk d.d. 8 februari i996, Rep. Eur. Court H.R. I996, I, 30, i.h.b. $\$ 45$.

II6 EHRM, arrest Saunders/Verenigd Koninkrijk d.d. I7 december I996, Rep. Eur. Court H.R. I996, VI, 2044, i.h.b. $\$ 68$.

II7 J. DU JARDIN, 'Het recht van verdediging in de rechtspraak van het Hof van Cassatie (I990-2003)', Plechtige openingsrede I september 2003, RW 2003-2004, 765; M. FRANCHIMONT, 'Les droits de la défense et leur contexte procédural, le discours et la réalité', in Les droits de la défense en matière pénale, Luik, Éd. du Jeune Barreau de Liège, $1985,42$.

II8 ECRM, advies d.d. 30 mei r9gr in de zaak Sténuit/Frankrijk, Publ. Cour, Sér. A, nr. 232 A, § 66.

II9 Brussel 2I mei 20I2, Dr.pén.entr. 20I2, I43.

I20 M. FAURE en P. WAETERINCKX, 'De strafrechtelijke verantwoordelijkheid van de rechtspersoon: een blik op de rechtspraak en enkele knelpunten uit de praktijk', T. Strafr. 2004, 338-339, nr. 5I; L. HUYBRECHTS en M. ROZIE, 'De rechten van verdediging bij de behandeling ten gronde', NC 2008, I20, nr. 80.

I2I S. COISNE en P. WAETERINCKX, 'La sauvegarde des droits de la défense d'une personne morale, son droit au silence et le mandataire ad hoc comme garant de ces droits', in La responsabilité pénale des personnes morales en Belgique, M. NIHOUL (ed.), Brussel, La Charte, 2005, 307 e.v. 
opgepikt in twee recente studies in $2015 .{ }^{122}$ Buiten deze studies is de oogst in de doctrine op dit punt nog steeds werkelijk schaars te noemen.

36. Waar het hierboven (onder I.) vooral ging over de vraag door wie de rechtspersoon vertegenwoordigd wordt in de strafprocedure - en dus in zekere zin: wie voor de rechtspersoon kan spreken - gaat het in dit onderdeel van het preadvies integendeel over de vraag wie namens de rechtspersoon kan zwijgen.

Men zou met een zeker cynisme kunnen voorhouden dat rechtspersonen uit hun aard niet kunnen spreken, zodat ze ook niet kunnen beslissen niet te spreken maar te zwijgen, of nog dat wie niet kan spreken, per definitie altijd zwijgt ... en op die manier de hele kwestie van de uitoefening van het zwijgrecht van de rechtspersoon naar de prullenmand verwijzen.

37. Rechtspersonen kunnen evenwel uit hun aard ook niet kunnen handelen. Dat betekent evenwel niet dat ze geen strafbare gedragingen kunnen stellen.

De hele conceptuele oefening bestaat er immers precies in de immateriële - sommigen blijven, tegen de wil van de wetgever ${ }^{123}$ in, zeggen: fictieve - aard van de rechtspersoon te omzeilen, teneinde een stelsel van strafrechtelijke verantwoordelijkheid op rechtspersonen van toepassing te kunnen maken.

Wat dat handelen betreft, heeft de Belgische wetgever ervoor geopteerd wettelijke criteria te ontwikkelen die bepalend zijn voor de vraag, of een welbepaald handelen (of nalaten) door een natuurlijke persoon kan worden beschouwd als handelen (of nalaten) door de rechtspersoon.

Die criteria zijn, zoals hierboven reeds vermeld (zie nr. 3), drieledig: een handeling (of onthouding) wordt geacht door een rechtspersoon te zijn gepleegd indien zij ofwel een intrinsiek verband heeft met de verwezenlijking van zijn doel, ofwel een intrinsiek verband heeft met de waarneming van zijn belangen, ofwel, naar blijkt uit de concrete omstandigheden, voor zijn rekening is gepleegd (art. 5, I ${ }^{\text {ste }}$ lid Sw.).

Het valt daarbij op dat deze criteria enkel betrekking hebben op de aard van de gedraging als dusdanig (alsook, in zekere mate, op haar effect voor de rechtspersoon) en uitdrukkelijk niet op de hoedanigheid van de persoon, die de gelaakte gedraging namens de rechtspersoon heeft gepleegd. Ondanks een afwijkend standpunt van de Raad van State - die van oordeel was dat de wetgever diende te preciseren 'wie de strafbaar ge-

I22 P. WAETERINCKX, De strafrechtelijke verantwoordelijkheid van de rechtspersoon en zijn leidinggevenden, Antwerpen-Cambridge, Intersentia, 20I5, i.h.b. I20 e.v. en P. WAETERINCKX, 'De (afgeleide) rechten van verdediging van de rechtspersoon. Heeft een rechtspersoon het recht te zwijgen, eventueel met of zonder bijstand van een raadsman?', NC 2015, 73-95.

I23 Reeds bij het begin van de toelichting bij het wetsvoorstel luidt het: 'In tegenstelling tot de visie die aan het advies van de Raad van State ten grondslag lijkt te liggen, wordt derhalve niet het fictiemodel gehanteerd, binnen hetwelk de rechtspersoon louter als een collectiviteit van natuurlijke personen wordt beschouwd.' (Parl. St., Senaat, I998-99, nr. I-I2I7/I, p. 2). De rechtspersoon is voor de wetgever integendeel een reële, sociale entiteit, die aan een sociologische realiteit beantwoordt en dus een eigen juridische en strafrechtelijke identiteit bezit (zie het verslag namens de Kamercommissie voor Justitie, Parl. St., Kamer, I998-99, nr. 2093/5, p. II, p. I3 en p. 22). 
stelde materiële handeling gepleegd moet hebben wil de rechtspersoon strafrechtelijk verantwoordelijk kunnen worden gesteld ${ }^{124}$ - is zulks niet meer dan logisch. Vanuit het hierboven vermelde autonome karakter van de strafrechtelijke verantwoordelijkheid van de rechtspersoon in België vloeit immers voort dat de natuurlijke persoon - die namens de rechtspersoon heeft gehandeld of nagelaten - niet hoeft te worden geïdentificeerd, opdat de rechtspersoon strafrechtelijk verantwoordelijk zou kunnen worden gesteld. ${ }^{125}$

38. Rechtspersonen handelen niet alleen uitsluitend via natuurlijke personen ${ }^{126}$ vermits zij geen eigen handen hebben, rechtspersonen spreken evenzeer uitsluitend via natuurlijke personen vermits zij geen mond hebben.

Ter beantwoording van de vraag wie namens de rechtspersoon kan of moet spreken - en wie bijgevolg tevens het zwijgrecht van de rechtspersoon kan uitoefenen - is het m.i. raadzaam, de hierna volgende hypothesen en deelhypothesen te onderscheiden.

a) Als de rechtspersoon als verdachte zelf het initiatief neemt om een verklaring af te leggen over het onderzoek of de tegen hem ingestelde strafvervolging, kan hij uiteraard zelf (via zijn raad van bestuur) de natuurlijke persoon aanwijzen die deze verklaring namens de rechtspersoon kan afleggen. Als de rechtspersoon besluit te spreken, kiest hij a.h.w. de mond waarmee dat zal gebeuren.

b) Wanneer het daarentegen de opsporingsambtenaren of de gerechtelijke autoriteiten zijn die het initiatief nemen de rechtspersoon te ondervragen, rijst de vraag of zij zich dan tot gelijk welke natuurlijke persoon binnen die rechtspersoon kunnen richten. Ik ben van oordeel dat het in deze hypothese niet aan de speurders of autoriteiten toekomt hun fysische 'gesprekspartner' te kiezen. Als het de bedoeling is de rechtspersoon te ondervragen en dus een verklaring van de verdachte rechtspersoon te bekomen, is het aan (de raad van bestuur van) de rechtspersoon om de natuurlijke persoon aan te duiden, die deze verklaring kan afleggen.

De daartoe afgevaardigde natuurlijke persoon heeft daarbij de vrijheid namens de rechtspersoon te antwoorden op de gestelde vragen of namens de rechtspersoon te zwijgen en op die manier het zwijgrecht van de rechtspersoon uit te oefenen. Vanuit de wens de autonomie van het Belgisch stelsel van strafrechtelijke verantwoordelijkheid te vrijwaren, verkies ik in dit verband te spreken over 'de uitoefening van het zwijgrecht van de rechtspersoon' en niet over 'de uitoefening van een afgeleid zwijgrecht' ${ }^{127}$ (met welk laatste dan

I24 Advies van de Raad van State bij het voorontwerp van wet, Parl. St., Senaat, I998-99, nr. I-I2I7/6, p. II7-II8. Zie tevens de algemene bespreking in de Senaatscommissie voor Justitie, Parl. St., Senaat, I998-99, nr. I-I2I7/6, p. I6.

I25 Zie de verklaring van de minister van Justitie tijdens de bespreking in de Senaatscommissie voor Justitie, Parl. St., Senaat, I998-99, nr. I-I217/6, p. I8.

I26 Zo wordt uitdrukkelijk opgemerkt in het verslag namens de Senaatscommissie voor Justitie, Parl. St., Senaat, I998-99, p. 38 .

I27 Zo R. VERSTRAETEN, 'Kritische beschouwingen bij het nieuwe strafrechtelijke aansprakelijkheidsregime voor rechtspersonen', in Nieuw vennootschaps- en financieel recht 1999, Kalmthout, Biblo, 2000, 243; vgl. P. WAETERINCKX, De strafrechtelijke verantwoordelijkheid van de rechtspersoon en zijn leidinggevenden, Antwerpen-Cambridge, Intersentia, 20I5, I25, die het heeft over 'afgeleide rechten van verdediging'. 
bedoeld wordt: de uitoefening van een zwijgrecht dat afgeleid is van dat van de rechtspersoon).

c) Als de opsporingsambtenaren of de gerechtelijke autoriteiten personen willen ondervragen over de feiten waarvan de rechtspersoon verdacht wordt - m.a.w. geen verklaring van de rechtspersoon willen bekomen, maar wel getuigenverklaringen nopens de feiten - zijn zij m.i. in principe - zoals steeds - vrij zich te richten tot diegenen, die naar hun oordeel nuttige gegevens m.b.t. die feiten zouden kunnen geven. Niettemin dienen m.i. twee deelhypothesen te worden onderscheiden.

c.I) Wenst men personen te ondervragen die niet werkzaam zijn voor de rechtspersoon, dan zijn deze personen te beschouwen als loutere getuigen en dienen zij te voldoen aan alle verplichtingen van de getuige (die de eed heeft afgelegd ${ }^{128}$ ), waaronder antwoorden op de gestelde vragen en daarbij de waarheid spreken. Als getuige hebben zij noch in eigen hoofde een zwijgrecht, noch kunnen zij het zwijgrecht van de rechtspersoon uitoefenen, nu het niet de rechtspersoon is die wordt ondervraagd.

c.2) Wenst men daarentegen personen te ondervragen die wel werkzaam zijn voor de rechtspersoon, is er wel beschouwd geen sprake van de ondervraging van een getuige. Twee verdere deelhypothesen moeten worden onderscheiden.

c.2.I) Ofwel richten de speurders zich tot een natuurlijke persoon die zelf verdacht wordt van de feiten, waarvan ook de rechtspersoon verdacht wordt. Dan gaat het om iemand die ondervraagd wordt als een verdachte, met alle gevolgen van dien en dus ook met de mogelijkheid niet te antwoorden op de gestelde vragen maar zich op zijn eigen zwijgrecht te beroepen.

c.2.2) Ofwel gaat het om iemand die niet verdacht wordt van die feiten. Ook dan moet m.i. aanvaard worden dat deze persoon - die werkzaam is voor de verdachte rechtspersoon - de mogelijkheid moet hebben om niet te antwoorden op de gestelde vragen, maar integendeel het zwijgrecht van de rechtspersoon uit te oefenen. Deze persoon kan immers niet beschouwd worden als een getuige: het onderscheid tussen een verdachte en een getuige wordt al te artificieel, indien iemand als getuige ondervraagd wordt over feiten waarvan de rechtspersoon, voor wie hij werkzaam is en daardoor zijn brood verdient, wordt verdacht.

I28 Getuigen leggen de eed af voor de onderzoeksrechter en voor de vonnisgerechten, niet voor de politieambtenaren en voor de procureur des Konings, tenzij deze laatste handelt bij heterdaad. De eed is evenwel niet voorgeschreven op straffe van nietigheid (Cass. 4 december 1950, Arr. Cass. I95I, I58). 
39. Ik ben er mij van bewust dat vooral het standpunt m.b.t. deze laatste deelhypothese - met name deze onder c.2.2: het verhoor van een natuurlijke persoon die werkzaam is voor de rechtspersoon, maar zelf niet verdacht wordt van de feiten tot verdere discussie kan leiden.

Zo zou volgens R. VERSTRAETEN het zwijgrecht van de rechtspersoon al te zeer worden uitgehold, indien alle natuurlijke personen die deel uitmaken van de rechtspersoon zonder meer als getuigen zouden kunnen worden gehoord. Het is volgens deze auteur moeilijk aan te nemen dat het personeel van de rechtspersoon zonder onderscheid zou kunnen worden verplicht om bewijs tegen de onderneming te leveren. ${ }^{129}$

Deze auteur suggereert dus dat er een onderscheid moet worden gemaakt tussen bepaalde voor de rechtspersoon werkzame natuurlijke personen die wel als getuige kunnen worden gehoord en andere dergelijke natuurlijke personen, waarbij dat niet het geval is.

Ook P. WAETERINCKX merkt op dat het niet evident is de kring van de natuurlijke personen te bepalen, die het zgn. 'afgeleide' recht van verdediging van de rechtspersoon tijdens een onderzoek kunnen uitoefenen. ${ }^{130}$

Het staat volgens deze auteur vast dat natuurlijke personen die de rechtspersoon vertegenwoordigen niet als getuige kunnen worden verhoord: nu ze de rechtspersoon die ze vertegenwoordigen a.h.w. incarneren, zou dit immers neerkomen op het horen van de rechtspersoon als getuige in zijn eigen zaak. Daarnaast lijkt het hem passend dit zgn. 'afgeleide' zwijgrecht ook uit te breiden tot opdrachtgevers en feitelijke leidinggevers zoals werfleiders, projectleiders of site-verantwoordelijken: de rechtspersoon handelt immers via deze fysieke personen en indien deze nadien zouden worden verhoord als getuige, zou het zwijgrecht uitgehold worden. Van de overige werknemers lijkt deze auteur aan te nemen dat zij daarentegen wel kunnen optreden als echte getuigen. ${ }^{\mathrm{I}}{ }^{\mathrm{I}}$

Een dergelijke inperking kan ook worden afgeleid uit de omzendbrief nr. 8/20II van het college van procureurs-generaal bij de hoven van beroep d.d. 23 september $20 I$ inzake de organisatie van de bijstand door een advocaat vanaf het eerste verhoor binnen het kader van het Belgisch strafprocesrecht. ${ }^{132}$

I29 R. VERSTRAETEN, 'Kritische beschouwingen bij het nieuwe strafrechtelijke aansprakelijkheidsregime voor rechtspersonen', in Nieuw vennootschaps- en financieel recht 1999, Kalmthout, Biblo, 2000, 243.

I30 P. WAETERINCKX, 'De rechtspersoon binnen het Salduz-kluwen' (noot onder Cass., 25 september 2012), RABG 2013, 39, nr. I9.

I3I P. WAETERINCKX, 'De (afgeleide) rechten van verdediging van de rechtspersoon. Heeft een rechtspersoon het recht te zwijgen, eventueel met of zonder bijstand van een raadsman?', NC 20I5, 85 , nr. 39 resp. $86-87$, nr. 42 .

I32 In het kader van dit preadvies is de kernvraag wie het zwijgrecht van de rechtspersoon kan uitoefenen. De kwestie van de bijstand van een raadsman tijdens het verhoor wordt hier niet behandeld, evenmin als in het Nederlandse preadvies. De lezer zij verwezen naar de in de beide vorige voetnoten aangehaalde doctrine. 
Ingevolge het arrest Salduz/Turkije d.d. 27 november 2008 van het Europese Hof in Straatsburg ${ }^{133}$ heeft de wet van ${ }^{3} 3$ augustus 201 in het Wetboek van Strafvordering (meer bepaald in artikel 47 bis Sv.) een onderscheid ingevoerd tussen drie categorieën van personen: ${ }^{34}$

- zij die worden verhoord, ongeacht in welke hoedanigheid zij worden verhoord (dit zijn getuigen of verdachten, die over de rechten van artikel 47 bis, § I Sv. beschikken);

- zij die worden verhoord over misdrijven die hen kunnen worden ten laste gelegd (dit zijn de niet van hun vrijheid beroofde verdachten, die over de rechten van artikel 47bis, § 2 Sv. beschikken);

- zij die worden verhoord terwijl ze van hun vrijheid zijn beroofd overeenkomstig de wet van 20 juli 1990 betreffende de voorlopige hechtenis ${ }^{135}$ (dit zijn de aangehouden verdachten, die over de rechten van artikel 47 bis, $\$ 3$ Sv. beschikken).

\section{Kort samengevat komt het hierop neer:}

- dat de getuige noch recht op een voorafgaand vertrouwelijk overleg met een advocaat, noch recht op bijstand van een advocaat tijdens het verhoor heeft;

- dat de niet van zijn vrijheid beroofde verdachte recht op een voorafgaand vertrouwelijk overleg met een advocaat heeft, in zoverre de feiten die hem kunnen worden ten laste gelegd een misdrijf betreffen waarvan de straf aanleiding kan geven tot het verlenen van een bevel tot aanhouding (dus een misdrijf strafbaar met een correctionele hoofdgevangenisstraf van een jaar of een zwaardere straf ${ }^{\mathrm{f}^{36}}$ );

- dat de aangehouden verdachte zowel recht op een voorafgaand vertrouwelijk overleg met een advocaat als recht op bijstand van een advocaat tijdens het verhoor heeft. ${ }^{137}$

I33 EHRM (Grote Kamer), arrest Salduz/Turkije d.d. 27 november 2008, NC 2009, 98.

I34 Wet van I3 augustus 20II tot wijziging van het Wetboek van Strafvordering en van de wet van 20 juli I990 betreffende de voorlopige hechtenis, om aan elkeen die wordt verhoord en aan elkeen wiens vrijheid wordt benomen rechten te verlenen, waaronder het recht om een advocaat te raadplegen en door hem te worden bijgestaan, BS 5 september 2011 .

Zie betreffende deze wet J. MEESE en P. TERSAGO, 'Het recht voor elkeen die wordt verhoord op consultatie van en bijstand door een advocaat na de 'Salduz-wet' van I3 augustus 20II', RW 20II2012, 934 e.v.

I35 Wet van 20 juli I99o betreffende de voorlopige hechtenis, BS I4 augustus I 990.

I36 Artikel I6, S I, I ${ }^{\text {ste }}$ lid van de wet van 20 juli I99o betreffende de voorlopige hechtenis.

I37 Althans voor alle verhoren vanaf de vrijheidsberoving en voorafgaand aan het verlenen van een aanhoudingsbevel door de onderzoeksrechter (dat binnen de 24 uren moet worden verleend, welke termijn eenmalig kan worden verlengd met 24 uren: art. I, $I^{\circ}$ en art. 2, resp. art. I5bis van de wet van 20 juli 1990 betreffende de voorlopige hechtenis), alsook voor het verhoor door de onderzoeksrechter, dat aan het verlenen van een aanhoudingsbevel moet voorafgaan (art. I6, § 2, $2^{\text {de }}$ lid van de wet van 20 juli 1990 betreffende de voorlopige hechtenis). Daarna is er geen recht op bijstand meer. Deze regeling zal moeten worden herbekeken in het licht van de Richtlijn 2013/48/EU van 20 oktober 2013 van het Europees Parlement en de Raad betreffende het recht op toegang tot een advocaat in strafprocedures en in procedures ter uitvoering van een Europees aanhoudingsbevel en het recht om een derde op de hoogte te laten brengen vanaf de vrijheidsbeneming en om met derden en consulaire autoriteiten te communiceren tijdens de vrijheidsbeneming (Pb.L. 6 november 20I3, afl. 294), door de lidstaten om te zetten tegen 27 november 20I6. Zie desbetreffend F. DERUYCK, Overzicht van het Belgisch strafprocesrecht, Brugge, die Keure, 20I4, I45-I46. 
Welnu, in de omzendbrief van het college van procureurs-generaal wordt vooreerst opgemerkt dat de wet van I 3 augustus 20II geschreven is vanuit het perspectief van het verhoor van natuurlijke personen, zodat - vermits een rechtspersoon niet van zijn vrijheid kan worden beroofd - de meeste bepalingen er niet op van toepassing zijn. Vervolgens beveelt de omzendbrief ${ }^{138}$ de volgende werkwijze aan:

- als de verhoorde natuurlijke persoon zelf strafrechtelijk verantwoordelijk zou kunnen zijn voor de feiten waarvan de rechtspersoon wordt verdacht, zijn de bepalingen inzake het verhoor onverkort van toepassing (dat is ook logisch, want dan is de natuurlijke persoon zelf een verdachte);

- als dat niet zo is, dan zal - bij het verhoor van een vertegenwoordiger van de rechtspersoon - uitgegaan worden van de strafdrempel van de ter sprake komende misdrijven, alsof die ten laste zouden kunnen gelegd worden van de natuurlijke persoon, bij het bepalen of deze het recht heeft op een voorafgaand vertrouwelijk overleg met een advocaat.

M.a.w.: enkel de vertegenwoordiger van de rechtspersoon zal, indien de strafdrempel het voorschrijft (m.a.w. indien de rechtspersoon verdacht wordt van een misdrijf, strafbaar met een correctionele gevangenisstraf van één jaar of meer), recht hebben op een voorafgaand vertrouwelijk overleg met een advocaat. Andere natuurlijke personen blijven dus, althans volgens deze aanbevolen werkwijze in de omzendbrief, verstoken van de mogelijkheid het recht van de rechtspersoon op een voorafgaand vertrouwelijk overleg met een advocaat uit te oefenen.

Ook in de omzendbrief wordt derhalve voor het verhoor van natuurlijke personen die weliswaar werkzaam zijn voor de rechtspersoon maar zelf niet verdacht worden van de feiten, een onderscheid gemaakt: enkel de vertegenwoordigers kunnen de rechten van verdediging van de rechtspersoon (meer bepaald het recht op een voorafgaand vertrouwelijk overleg met een advocaat) uitoefenen, de andere natuurlijke personen niet. Die laatste kunnen dus worden verhoord als getuige, m.a.w. zonder recht op voorafgaand vertrouwelijk overleg met een advocaat.

40. Er is m.i. evenwel geen aanleiding in de hierboven besproken deelhypothese onder c.2.2 nog een onderscheid te maken tussen organen en/of wettelijke vertegenwoordigers en/of opdrachtgevers of feitelijke leidinggevers aan de ene kant en andere aangestelden, lasthebbers en dgl. aan de andere kant, waarbij dan alleen de eerste categorie de rechten van verdediging van de rechtspersoon en meer bepaald zijn zwijgrecht zou mogen uitoefenen.

$\mathrm{Nu}$ - terecht - aanvaard wordt dat de gedraging van gelijk welke natuurlijke persoon binnen de rechtspersoon als een gedraging van de rechtspersoon kan worden aangemerkt en dus tot de strafrechtelijke verantwoordelijkheid van die rechtspersoon kan leiden, moet evenzeer aanvaard worden dat de verklaring van gelijk welke natuurlijke persoon binnen die rechtspersoon uiteindelijk als een verklaring van de rechtspersoon dient te worden aangemerkt, zodat bij het af-

I38 Meer bepaald op p. 94 van de omzendbrief. 
leggen van die verklaring ook het zwijgrecht van de rechtspersoon kan worden uitgeoefend.

Gelijk wie taken uitvoert voor de rechtspersoon kan de strafrechtelijke verantwoordelijkheid van de rechtspersoon in het gedrang brengen en kan derhalve ook het zwijgrecht van de rechtspersoon uitoefenen.

Een rechtspersoon heeft vele handen om misdrijven te plegen, hij heeft evenwel ook vele monden om te spreken of te zwijgen ...

4I. De vraag rijst of bovenstaande stellingname m.b.t. de uitoefening van het zwijgrecht van de rechtspersoon wordt doorkruist, indien over de rechtspersoon een lasthebber ad hoc werd aangesteld.

In de doctrine werd daarover opgemerkt dat het geen twijfel lijdt, dat de lasthebber ad hoc het (afgeleid) zwijgrecht van de rechtspersoon kan uitoefenen. ${ }^{\mathrm{I} 9}$

In de mate als lasthebber ad hoc een andere vertegenwoordiger van de rechtspersoon zou worden aangeduid, kan dit standpunt onderschreven worden.

Indien men evenwel in herinnering brengt dat als lasthebber ad hoc in de praktijk meestal 'lukraak' een advocaat wordt aangesteld die dus per definitie over de feiten niets kan zeggen (noch als getuige, noch als verdachte), rijst de vraag waarover die lasthebber ad hoc dan wel zou kunnen zwijgen. Als men bovendien de taak en de bevoegdheden van die lasthebber ad hoc in herinnering brengt - met name het waarborgen van een onafhankelijke verdediging van de rechtspersoon, ofwel zelf, ofwel via een door hem aangestelde raadsman (zie hierboven, nr. 25) - lijkt de vraag of de lasthebber ad hoc een zwijgrecht heeft, mij eerder een valse vraag te zijn. De lasthebber ad hoc spreekt niet immers voor de rechtspersoon, maar verdedigt hem. Hij vervangt a.h.w. niet alleen de rechtspersoon, maar ook de door de rechtspersoon aangeduide advocaat.

Het is dus alsof men de vraag zou stellen of diegene die optreedt als advocaat een zwijgrecht heeft ... Men kan zich zelfs afvragen of de rechtspersoon nog wel via de lasthebber ad hoc kan worden ondervraagd. Nu de figuur van de lasthebber ad hoc door de rechtspraak van het Hof van Cassatie en het Grondwettelijk Hof is uitgegroeid tot wat zij in de hedendaagse praktijk is geworden, ben ik geneigd deze vraag ontkennend te beantwoorden.

Zo beschouwd wordt bovenstaande stellingname m.b.t. de uitoefening van het zwijgrecht van de rechtspersoon dus niet doorkruist door de aanduiding van een lasthebber ad hoc.

I39 M. FAURE en P. WAETERINCKX, 'De strafrechtelijke verantwoordelijkheid van de rechtspersoon: een blik op de rechtspraak en enkele knelpunten uit de praktijk', T. Strafr. 2004, 338-339, nr. 5I; R. VERSTRAETEN, 'Kritische beschouwingen bij het nieuwe strafrechtelijke aansprakelijkheidsregime voor rechtspersonen', in Nieuw vennootschaps- en financieel recht 1999, Kalmthout, Biblo, 2000, 243 . 
42. Bovenstaand principieel standpunt m.b.t. de uitoefening van het zwijgrecht van de rechtspersoon leidt er geenszins toe dat misdrijven die door rechtspersonen worden gepleegd, niet zouden kunnen worden opgespoord en aan het licht gebracht.

Vooreerst kan de natuurlijke persoon die ofwel zelf verdacht wordt (en dus zijn eigen zwijgrecht kan uitoefenen) ofwel niet verdacht is, maar voor de rechtspersoon werkzaam is (en dus het zwijgrecht van de rechtspersoon mag uitoefenen), ervoor opteren om te antwoorden op de gestelde vragen. Hij heeft immers - vanuit strafprocesrechtelijk oogpunt - een zwijgrecht en geen zwijgplicht. In de praktijk wordt in het kader van economische en financiële strafzaken overigens meestal meegewerkt aan het onderzoek en komt een beroep op het zwijgrecht niet al te vaak voor.

Of diegene die het zwijgrecht van de rechtspersoon mag uitoefenen daartoe geinstrueerd mag worden door de (raad van bestuur van) de rechtspersoon, is een kwestie van arbeidsrechtelijke, statutaire of contractuele aard, waarover ik me niet kan uitspreken. Aan de ene kant is dat vanuit strikt strafrechtelijk oogpunt niet het geval, aan de andere kant is het niet omdat een rechtspersoon verdacht wordt van een misdrijf, dat dan alleen nog het strafrecht van tel zou zijn en de andere rechtstakken niet meer zouden bestaan.

Voorts kunnen natuurlijke personen die niet voor die rechtspersoon werkzaam zijn wel degelijk als getuige worden verhoord met alle verplichtingen die daaruit voortvloeien, meer bepaald de verplichting naar waarheid te antwoorden op de gestelde vragen. De wetgever heeft niet voor niets bij herhaling benadrukt dat rechtspersonen geen fictie zijn, maar een sociale realiteit, die dus interacteert met andere sociale realiteiten: banken, medecontractanten, overheden, klanten ... De activiteiten van een rechtspersoon verbinden hem dus op velerlei wijze met tal van natuurlijke personen, die nuttig - en als getuige - kunnen worden verhoord.

Tenslotte dient herhaald te worden (zie hierboven, nr. 30) dat tal van andere daden van onderzoek, zoals bv. de huiszoeking en de inbeslagname van documenten, het doorzoeken van informaticasystemen en dgl. de waarheid aan het licht kunnen brengen. Op enkele van die daden van onderzoek wordt hierna (onder III) overigens nog kort ingegaan.

43. De wetgever heeft in artikel 5 Sw. een aantal criteria opgesomd die bepalend zijn voor de vraag, of een strafrechtelijk relevant handelen (of nalaten) van een natuurlijke persoon kan worden beschouwd als handelen (of nalaten) van de rechtspersoon. De 'onstoffelijke' ${ }^{\prime 40}$ aard van de rechtspersoon verplichtte de wetgever daartoe.

De wetgever heeft tevens gemeend, in artikel 2 bis V.T.Sv. en in de artikelen ${ }^{5} 2$ en $185 \mathrm{~Sv}$., een regeling te moeten treffen voor de vertegenwoordiging en de

I40 Memorie van toelichting bij het voorontwerp van wet, geciteerd in het advies van de Raad van State, Parl. St., Senaat, I998-99, nr. I-I2I7/6, p. II7. 
verschijning van de rechtspersoon. De 'onlichamelijke' ${ }^{{ }^{14 \mathrm{I}}}$ aard van de rechtspersoon verplichtte de wetgever daartoe.

De wetgever zou er m.i. ook goed aan doen te definiëren door wiens toedoen de rechtspersoon zijn zwijgrecht kan uitoefenen. Niet alleen de onstoffelijke of onlichamelijke aard van de rechtspersoon noopt daartoe, maar ook de onbevredigende situatie in de praktijk, waarin vaak voor de rechtspersoon werkzame natuurlijke personen worden verhoord als getuige en aldus bewijs dienen te leveren m.b.t. de verdenkingen die op die rechtspersoon rusten. ${ }^{142}$

Naar mijn oordeel zou zo'n wettelijke definitie - van wanneer of hoe een rechtspersoon spreekt en wanneer of hoe hij dus ook kan beslissen te zwijgen - best uitgaan van de diverse hypothesen en deelhypothesen die hierboven (nr. 38) werden onderscheiden.

\section{De positie van de rechtspersoon bij enkele daden van onderzoek}

44. In het Nederlands preadvies zijn naast de kwesties van de vertegenwoordiging en het zwijgrecht van de rechtspersoon - die ook daar het grootste gedeelte van het preadvies inpalmen - nog enkele andere onderwerpen aan bod gekomen die vanuit Nederlands recht als problematisch worden ervaren. Het gaat meer bepaald om de positie van de rechtspersoon (in het licht van zijn rechten van verdediging) bij een aantal daden van onderzoek.

Hierna worden deze daden van onderzoek met het oog op de rechtsvergelijking ook naar Belgisch recht kort toegelicht. Hoewel bij deze daden van onderzoek ook naar Belgisch recht wellicht bepaalde kanttekeningen zouden kunnen worden geplaatst in het licht van de rechten van verdediging, zijn deze problemen veelal niet specifiek voor de uitoefening van de rechten van verdediging van rechtspersonen, maar zijn ze gemeenschappelijk voor de uitoefening van de rechten van verdediging van zowel natuurlijke als rechtspersonen.

Er zal hierna dan ook enkel stilgestaan worden bij aspecten die specifiek zijn voor de rechten van verdediging van de rechtspersoon.

Vooreerst gaat het over de huiszoeking en andere vergelijkbare regelingen van toegang tot de bedrijfsgebouwen van de rechtspersoon. De kwestie van de toestemming van de rechtspersoon komt hierin eveneens aan bod.

Daarna gaat het om de medewerkingsverplichtingen, in het bijzonder bij het overleggen van bedrijfsdocumenten.

I4I Verslag namens de Senaatscommissie voor Justitie, Parl. St., Senaat, I998-99, nr. I-I2I7/6, p. 87.

I42 En waarbij die natuurlijke personen die aanvankelijk als getuige werden verhoord, nadien toch, samen met de rechtspersoon, worden vervolgd voor de feiten waarover zij werden gehoord ... maar dat is een ander probleem, dat de perken van dit preadvies overschrijdt. 


\section{III.I Huiszoeking en aanverwante regelingen}

45. Een huiszoeking is een onderzoeksmaatregel die zowel een inbreuk uitmaakt op de onschendbaarheid van woning, gewaarborgd door artikel I5 van de Grondwet, als op het recht op eerbiediging van het privéleven, het gezinsleven, het huis en de briefwisseling, gewaarborgd door artikel 8 van het EVRM. ${ }^{\mathrm{I} 33}$

Dat betekent, o.a., dat geen huiszoeking plaats kan hebben dan in de gevallen die de wet bepaalt en in de vorm die zij voorschrijft.

Het begrip 'woning' in de zin van artikel I5 van de Grondwet wordt volgens een vaste rechtspraak van het Hof van Cassatie omschreven als de plaats, met inbegrip van de erdoor omsloten aanhorigheden, die een persoon bewoont om er zijn werkelijke verblijfplaats te vestigen en waar hij uit dien hoofde recht heeft op eerbiediging van zijn persoonlijke levenssfeer, zijn rust en meer in het algemeen zijn privéleven. ${ }^{\mathrm{I} 4}$ Het is in deze klassieke zin, zoals een auteur het ooit omschreef, de plaats 'où l'on a sa pipe et ses pantoufles'. ${ }^{145}$

Het begrip 'huis' in de zin van artikel 8 van de Grondwet is onmiskenbaar ruimer. Volgens het Europees Hof voor de Rechten van de Mens kan het immers ook de kantoren omvatten waar de beoefenaar van een vrij beroep zijn werkzaamheden uitoefent, ${ }^{\mathrm{I} 46}$ evenals de lokalen die dienstig zijn voor commerciële activiteiten, zoals de hoofdzetel, de filialen of andere bedrijfsgebouwen van een vennootschap. ${ }^{\text {I47 }}$

Met F. VAN VOLSEM kan vastgesteld worden dat het Hof van Cassatie is opgeschoven in de richting van de Straatsburgse rechtspraak. In een arrest van ig februari 2002 werd immers aangenomen dat het in artikel 8 van het EVRM erkende recht ook bedrijfsruimten omvat, in de mate dat de daar ontwikkelde activiteiten een privékarakter vertonen of er vertrouwelijke briefwisseling wordt bewaard. ${ }^{148}$

46. Het recht tot huiszoeking komt in de regel toe aan de onderzoeksrechter (art. 87 Sv.). Hij kan de huiszoeking ook, middels een met redenen omkleed huiszoekingsbevel, delegeren aan een officier van gerechtelijke politie, wanneer dit noodzakelijk is $^{149}$ (art. 8gbis Sv.).

I43 R. VERSTRAETEN, Handboek Strafuordering, Antwerpen/Apeldoorn, Maklu, 2012, 324, nr. 588.

I44 Zie o.m. Cass. 23 juni I993, Arr. Cass. I993-94, 624; Cass. 2I april I998, RW I998-99, I452, noot A. VANDEPLAS; Cass. 26 oktober 2004, Arr. Cass. 2004, 1695.

I45 A. VANDEPLAS, 'Huiszoeking in een flatgebouw' (noot onder Cass. I4 januari I987), RW I986-87, 2784 , nr. I.

I46 EHRM, arrest Niemietz/Bondsrepubliek Duitsland d.d. I6 december I992, Publ. Eur. Court H.R. I992, Serie A, nr. 25I-B, i.h.b. § 29 e.v.

I47 EHRM, arrest Colas Est e.a./Frankrijk d.d. I6 april 2002, CEDH 2002-III, I05 e.v., i.h.b. § 4I. Zie recent tevens EHRM, arrest Delta Pekarny A.S./Tsjechië d.d. 2 oktober 20I4, weergave in NJB 20I5, afl. 3 , I90, i.h.b. $\$ 77$.

I48 Cass. Ig februari 2002, Arr. Cass. 2002, 535.

I49 Wat in de praktijk zeer vaak het geval blijkt te zijn. De motivering luidt dan steevast als volgt: 'Door andere ambtsverplichtingen verhinderd ...'. 
Overeenkomstig artikel $\mathrm{I}, 2^{\text {de }}$ lid, $3^{\circ}$ van de wet van 7 juni $1969^{150}$ kan evenwel een huiszoeking worden uitgevoerd, zowel overdag als 's nachts, ${ }^{15 \mathrm{I}}$ indien de persoon die het werkelijk genot heeft van het huis ${ }^{152}$ daarom verzoekt of daarin toestemt.

Dergelijke toestemming moet, overeenkomstig artikel Ibis van deze wet, schriftelijk en voorafgaand aan de huiszoeking worden gegeven, dit uiteraard om bewijsproblemen te vermijden.

Wanneer het gaat om bedrijfsterreinen, bedrijfsruimten en bedrijfslokalen die toebehoren aan een rechtspersoon, kan deze toestemming volgens een unanieme rechtsleer slechts worden verleend door degene die de rechtspersoon kan vertegenwoordigen, zoals een bestuurder of een zaakvoerder, of nog elke daartoe gemandateerde persoon. ${ }^{53}$

Natuurlijke personen die de rechtspersoon niet kunnen vertegenwoordigen (zoals bv. het personeel aan de onthaalbalie of de huisbewaarder, of nog degene die als aangestelde een kantoor ter beschikking heeft), kunnen dus geen geldige toestemming verlenen.

47. De hierboven beschreven regeling is uiteraard slechts van toepassing op private plaatsen, m.a.w. op niet voor het publiek toegankelijke plaatsen. ${ }^{154}$ Overeenkomstig artikel 26 van de wet van 5 augustus 1992 op het politieambt ${ }^{155}$ kunnen politieambtenaren steeds de voor het publiek toegankelijke plaatsen ${ }^{156}$ betreden, teneinde toe te zien op de handhaving van de openbare orde of teneinde opdrachten van gerechtelijke politie uit te oefenen.

Dit recht tot betreding - dat niet volledig gelijkgeschakeld kan worden met het recht tot huiszoeking ${ }^{157}$ - heeft bv. betrekking op de ruimten waartoe de klanten of bezoekers van de rechtspersoon toegang hebben, zoals ontvangstruimten, winkelruimten en dgl.

Ondanks het gebruik van het woord 'steeds' in de betrokken wetsbepaling, wordt aangenomen dat de politieambtenaren de plaatsen enkel mogen betreden gedurende de tijdsperiode dat ook het publiek toegang tot de plaatsen heeft..$^{158}$

I50 Wet van 7 juni 1969 tot vaststelling van de tijd gedurende welke geen opsporingen ten huize of huiszoekingen mogen worden verricht, BS 28 juni ig69.

I5I In de regel is een huiszoeking enkel mogelijk tussen 5 uur's morgens en 2I uur 's avonds (artikel I, I $^{\text {ste }}$ lid van de wet van 7 juni I $_{9} 69$ ).

I52 Alsook de persoon die bedoeld wordt in artikel $46,2^{\circ} \mathrm{Sv}$., met name het slachtoffer van partnergeweld.

I53 J. SMETS (geactualiseerd door S. VANDROMME), 'Huiszoeking met toestemming', in Strafrecht en Strafvordering. Commentaar met overzicht van rechtspraak en rechtsleer, Mechelen, Wolters-Kluwer, losbl., II, nr. 23; S. VANDROMME, 'De huiszoeking: de principes en de toepassing ervan in de rechtspraak', in Het onroerend goed in het straf(proces)recht, Antwerpen-Cambridge, Intersentia, 2012, I58, nr. 27; R. VERSTRAETEN, Handboek Strafuordering, Antwerpen/Apeldoorn, Maklu, 2012, 329, nr. 598.

I54 Zie nogmaals artikel I van de wet van 7 juni I969, dat het in zijn eerste lid heeft over 'een voor het publiek niet toegankelijke plaats'.

I55 BS 22 december 1992.

I56 Alsook de verlaten onroerende goederen, waarover het in dit preadvies verder niet zal gaan.

I57 R. VERSTRAETEN, Handboek Strafvordering, Antwerpen/Apeldoorn, Maklu, 2012, 332, nr. 604.

I58 Memorie van toelichting bij het wetsontwerp op het politieambt, Parl. St., Kamer, I990-9I, nr. I637/I, p. 44 . 
Indien de onderzoeksmaatregel dus meer beoogt dan het betreden van de plaats, of nog het betreden van die plaats beoogt buiten de periode dat ze voor het publiek toegankelijk is, dient in principe de gewone regeling te worden toegepast (m.a.w. een huiszoekingsbevel te worden afgeleverd door de onderzoeksrechter, of toestemming te worden gegeven).

48. Ook in de bijzondere wetgeving, bv. in het kader van het economisch en financieel strafrecht ${ }^{159}$ of nog in kader van het sociaal strafrecht, ${ }^{160}$ worden vaak betredings- of toegangsregelingen opgenomen.

Typevoorbeeld is artikel XV.3 van het Wetboek van Economisch Recht ${ }^{16 \mathrm{I}}$ van $28 \mathrm{fe}-$ bruari 2013.

Luidens die bepaling kunnen de door de minister (bevoegd voor Economische Zaken) aangeduide ambtenaren - het gaat in de praktijk vooral om ambtenaren van de Economische Algemene Inspectie die opsporingsbevoegdheden hebben bekomen - met het oog op het opsporen en vaststellen van inbreuken op de bepalingen van het Wetboek en zijn uitvoeringsbesluiten ${ }^{162}$ zich tijdens de gewone openings- of werkuren, tijdens het productieproces of op het ogenblik dat de producten of diensten worden aangeboden, toegang verschaffen tot of zich toegang laten verschaffen tot alle plaatsen waarvan zij op redelijke gronden van oordeel zijn dat de betreding ervan voor het vervullen van hun taak noodzakelijk is (art. XV.3, $\mathrm{I}^{\circ}, \mathrm{I}^{\text {ste }}$ lid W.E.R.).

Gaat het om bewoonde lokalen, dan kunnen deze worden betreden na voorafgaande en schriftelijke toestemming van de bewoner (art. XV.3, $\mathrm{I}^{\circ}, 3^{\text {de }}$ lid W.E.R.).

Indien zij redenen hebben te geloven aan het bestaan van een inbreuk kunnen zij bij ontstentenis van toestemming in de bewoonde lokalen slechts binnentreden na voorafgaand een gemotiveerde, schriftelijke, ondertekende en gedagtekende machtiging van de onderzoeksrechter te hebben bekomen. Zij kunnen de bewoonde lokalen dan betreden tussen 5 uur's morgens en 2I uur's avonds ${ }^{163}$ en op voorwaarde dat ten minste twee ambtenaren gezamenlijk optreden (art. XV.3, I $^{\circ}, 4^{\text {de }}$ lid W.E.R.).

In tegenstelling tot artikel 26 van de wet van 5 augustus 1992 op het politieambt (zie hierboven, nr. 47) wordt in artikel XV.3 W.E.R. uitdrukkelijk bepaald dat het betredingsrecht maar geldt tijdens de gewone openings- of werkuren. ${ }^{164}$

I59 Zie hierover uitvoerig F. LUGENTZ, 'Les perquisitions en matière économique et financière', Dr.pén.entr. 2009, 23-52 en 225-242.

I6o In samenspraak met de Nederlandse preadviseur en om de maximaal toegelaten omvang van de preadviezen niet al te zeer te overschrijden, wordt het sociaal strafrecht hier buiten beschouwing gelaten. Zie hierover K. SALOMEZ, Sociaal strafrecht, Brugge, die Keure, 2010, 98-108; W. VAN EECKHOUTTE en S. BOUZOUMITA, 'Opsporing van sociaalrechtelijke misdrijven', in Sociaal handhavingsrecht, G. VAN LIMBERGHEN (ed.), Antwerpen/Apeldoorn, Maklu, 2010, I76-I82.

I6I Hierna W.E.R.

I62 Met uitzondering van Boek IV en zijn uitvoeringsbesluiten (m.b.t. de bescherming van de mededinging).

I63 Vgl. met de gemeenrechtelijke regeling (zie hierboven, $\mathrm{nr} .46$ ) in artikel I, $\mathrm{I}^{\text {ste }}$ lid van de wet van 7 juni ig69.

I64 Voor de opsporing en vaststelling van de inbreuken op de bepalingen van Boek IX en Boek XI van het W.E.R., resp. betreffende de veiligheid van producten en diensten en de intellectuele eigendom, geldt deze tijdsbeperking niet. De ambtenaren kunnen zich dus in dat geval te allen tijde toegang verschaffen of laten verschaffen (art. XV.3, $\mathrm{I}^{\circ}, 2^{\text {de }}$ lid W.E.R.). 
In de zaak die tot het arrest van het Hof van Cassatie van 30 november 2004 aanleiding gaf, hadden de beste klanten van een kledingzaak (met name deze die in de voorbije twee jaren het meest hadden gekocht) een persoonlijke uitnodiging ontvangen om na 20 uur, op een ogenblik dat de winkel voor de niet-uitgenodigde klanten gesloten was, als eerste de kans te krijgen om de zgn. koopjesperiode te benutten. Een ambtenaar van de Economische Algemene Inspectie had de winkelruimte betreden ${ }^{165}$ om de overtreding van de zgn. sperperiode vast te stellen. De verdediging had aangevoerd dat zijn vaststellingen onregelmatig waren vermits hij de winkel had betreden buiten de gewone openingsuren. In eerste aanleg pakte dat nog, ${ }^{166}$ maar niet meer in hoger beroep: het ging om een winkelruimte in volle bedrijvigheid, met personeel en winkelend en kopend cliënteel en de omstandigheid dat de winkel gesloten was voor niet-uitgenodigde klanten, doet daaraan niets af. Het Hof van Cassatie bevestigde deze zienswijze: onder de gewone openingsuren moeten worden verstaan de uren dat de verkoper in zijn winkelruimte hetzij de consumenten die datwensen, hetzij zijn bestaande cliënteel of een categorie daarvan toelaat. ${ }^{167}$

49. Volledigheidshalve vermeld ik nog de zgn. inkijkoperatie. De wetgever heeft deze daad van onderzoek aanvankelijk ingevoerd door de wet van 6 januari 2003 betreffende de bijzondere opsporingsmethoden en enige andere onderzoeksmethoden. ${ }^{168} \mathrm{Hij}$ omschreef de inkijkoperatie daarbij als een onderzoeksmaatregel die aanleunt bij de bijzondere opsporingsmethoden (maar dus een zgn. 'andere methode' is) en die het heimelijk betreden van private plaatsen, met inbegrip van de woning, tot doel heeft. ${ }^{169}$

De inkijkoperatie werd aanvankelijk enkel ingevoerd in het kader van het gerechtelijk onderzoek, meer bepaald in artikel 8gter Sv. ${ }^{170}$ Nadat verschillende bepalingen van de wet van 6 januari 2003 door het toenmalige Arbitragehof werden vernietigd, ${ }^{171}$ werd de regeling van de inkijkoperatie in artikel 8gter Sv. opnieuw ingevoerd door de wet van 27 december 2005. ${ }^{172}$ Deze wet voerde evenwel tevens een regeling van de inkijkoperatie in tijdens het opsporingsonderzoek, meer bepaald in artikel 46 quinquies Sv. ${ }^{173}$

I65 Op basis van een voorloper van artikel XV.3 W.E.R., met name artikel II3, $\S 2, I^{\circ}$ van de wet op de handelspraktijken en de voorlichting en bescherming van de consument van I4 juli I99I, BS 29 augustus I99I.

I66 Corr. Gent 3 oktober 200I, Jaarboek Handelspraktijken en Mededinging 2001, 799, noot D. VAN DAELE, 'De strafrechtelijke handhaving van de Handelspraktijkenwet'.

I67 Cass. 30 november 2004, NC 2006, 245, noot B. VANGEEBERGEN en D. VAN DAELE, 'Over gewone openingsuren en voor het publiek toegankelijke plaatsen'. Vgl. reeds een gelijkaardig geval in Corr. Turnhout, I4 februari 1997, RW 1997-98, 343, noot A. VANDENPLAS, 'Over de opsporingsbevoegdheden van de ambtenaren inzake handelspraktijken'.

I68 BS I2 mei 2003.

I69 Memorie van toelichting bij het wetsontwerp betreffende de bijzondere opsporingsmethoden, Parl. St., Kamer, 2001-02, nr. I688/001, p. 56.

I70 A. DE NAUW en F. SCHUERMANS, 'De wet betreffende de bijzondere opsporingsmethoden en enige andere onderzoeksmethoden', RW 2003-04, 950, nr. 97.

I7I Arbitragehof, arrest nr. 202/2004 van 2I december 2004, BS 6 januari 2005.

172 Wet van 27 december 2005 houdende diverse wijzigingen van het Wetboek van Strafvordering en van het Gerechtelijk Wetboek met het oog op de verbetering van de onderzoeksmethoden in de strijd tegen het terrorisme en de zware en georganiseerde criminaliteit, BS 30 december 2005 .

173 Zie hierover, kritisch, J. MEESE, 'De BOM-wet "revisited": een overzicht van de wijzigingen sedert de Wet van 27 december 2005', NC 2006, I49-I50. 
In het kader van het opsporingsonderzoek kan de procureur des Konings de politiediensten machtigen om een private plaats te betreden buiten het medeweten van de eigenaar of van zijn rechthebbende. ${ }^{174}$

Deze maatregel is enkel mogelijk indien er ernstige aanwijzingen zijn dat de strafbare feiten een misdrijf zouden uitmaken zoals bedoeld in artikel goter, $\$ 2$ tot 4 Sv., ${ }^{175}$ of dat de feiten gepleegd zouden worden in het kader van een criminele organisatie zoals bedoeld in artikel 324 bis Sw. Bovendien is vereist dat de andere middelen van onderzoek niet lijken te volstaan om de waarheid aan het licht te brengen: dit is het vereiste van subsidiariteit.

Het betreden van de plaats kan enkel geschieden teneinde de plaats op te nemen en zich te vergewissen van de eventuele aanwezigheid van zaken als bedoeld in artikel 42 Sw. (m.a.w.: die vatbaar zijn voor verbeurdverklaring), teneinde de bewijzen te verzamelen van de aanwezigheid van dergelijke zaken of teneinde in het kader van een observatie een technisch hulpmiddel te plaatsen als bedoeld in artikel 47 sexies, $§$ I, $3^{\text {de }}$ lid Sv. ${ }^{176}$

In het kader van het opsporingsonderzoek is de inkijkoperatie enkel mogelijk in een private plaats die geen woning is, geen door een woning omsloten aanhorigheid is en geen lokaal is dat aangewend wordt voor de beroepsdoeleinden of voor de woonplaats van een advocaat of een arts. De wetgever dacht daarbij weliswaar 'alleen' aan opslagplaatsen, loodsen, containers en afgesloten garageboxen en preciseerde daarbij dat de procureur des Konings uiterst voorzichtig zal moeten zijn, wil hij voorkomen dat de procedure naderhand te niet wordt gedaan ${ }^{177} \ldots$ maar de

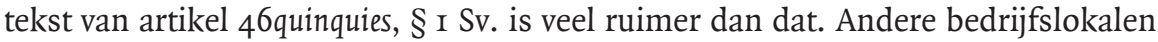
dan deze die worden gebruikt door een advocaat of een arts kunnen immers wel degelijk het voorwerp kunnen uitmaken van een inkijkoperatie die bevolen wordt door het openbaar ministerie, ${ }^{178}$ hoewel deze bedrijfslokalen toch ook onder de bescherming van artikel 8 van het EVRM kunnen vallen (zie hierboven, nr. 45).

I74 De wet voegt daar, ietwat eigenaardig, aan toe: 'of zonder hun toestemming'. Als de private plaats kan betreden worden buiten het medeweten van de eigenaar, impliceert dat immers dat deze geen toestemming kon geven. Zie voor een verdienstelijke poging toch een coherente uitleg voor deze zinsnede te geven B. VAN GEEBERGEN, 'Inkijkoperatie', in Strafrecht en Strafuordering. Commentaar met overzicht van rechtspraak en rechtsleer, Mechelen, Wolters-Kluwer, losbl., 7, nr. 9 en ro.

I75 In deze wetsbepaling worden de misdrijven opgesomd waarvoor het afluisteren van telefoongesprekken mogelijk is. In die opsomming staat, o.a., het misdrijf van witwassen (artikel 505, ${ }^{\text {ste }}$ lid, $2^{\circ}, 3^{\circ}$ en $4^{\circ} \mathrm{Sw}$.), wat de inkijkoperatie in één klap relevant maakt voor het economisch strafrecht waarin dat misdrijf nu eenmaal, als sluitstuk van de vervolging, zeer vaak ten laste wordt gelegd.

I76 In deze bepaling wordt een technisch hulpmiddel omschreven als 'een configuratie van componenten die signalen detecteert, deze transporteert, hun registratie activeert en de signalen registreert', voor wie hiervan iets zou begrijpen ...

I77 Memorie van toelichting bij het wetsontwerp, Parl. St., Kamer, 2005-o6, nr. 2055/oor, p. I6; verslag namens de Kamercommissie voor Justitie, Parl. St., Kamer, 2005-06, nr. 2055/005, p. 20.

I78 J. MEESE vraagt zich terecht af waarom, als dat dan toch de enige plaatsen zijn waar de wetgever aan dacht, bedrijfslokalen dan niet expliciet uit het toepassingsgebied van de inkijkoperatie tijdens het opsporingsonderzoek werden uitgesloten: 'De BOM-wet "revisited": een overzicht van de wijzigingen sedert de Wet van 27 december 2005', NC 2006, I50, nr. Io. 
Gaat het om een andere private plaats dan deze die bedoeld worden in artikel 46quinquies, § I Sv. - m.a.w. gaat het wel om een woning, om een door een woning omsloten aanhorigheid of om een lokaal dat aangewend wordt voor de beroepsdoeleinden of voor de woonplaats van een advocaat of een arts - dan dient de machtiging tot de inkijkoperatie te worden verleend door de onderzoeksrechter, zodat de inkijkoperatie dan enkel mogelijk is in het kader van een gerechtelijk onderzoek. ${ }^{179}$

De inkijkoperatie lijkt ongetwijfeld op een huiszoeking, maar verschilt daarvan niettemin op een drietal vlakken. ${ }^{80}$

Vooreerst is de inkijkoperatie heimelijk en geschiedt ze buiten medeweten van de eigenaar van de woning of het lokaal, daar waar de huiszoeking in de regel geschiedt in aanwezigheid van de verdachte of van de bewoner van het huis. In elk geval, ook bij hun afwezigheid, zullen zij van de huiszoeking op de hoogte worden gesteld.

Voorts beperkt de inkijkoperatie zich tot het opnemen van de plaats, dus tot het zgn. zoekend rondkijken. Een echte doorzoeking (door bv. kasten open te breken) is enkel mogelijk in het kader van een huiszoeking.

Tenslotte is de inkijkoperatie er op gericht de aanwezigheid van bepaalde zaken vast te stellen, zonder deze in beslag te kunnen nemen. Dat laatste is in principe enkel mogelijk in het kader van een huiszoeking.

\section{III.2 Medewerkingsverplichtingen, i.h.b. de overlegging van documenten}

50. In het Wetboek van Strafvordering zijn op meerdere plaatsen medewerkingsverplichtingen opgenomen. Voorbeelden zijn de medewerking die door de procureur des Konings en/of de onderzoeksrechter kan gevorderd worden van een arts in geval van een gewelddadige of verdachte dood of nog van een dood waarvan de oorzaak onbekend is (art. $44 \mathrm{~Sv}$.) of in geval van dronkenschap (art. 44bis Sv.), de medewerking van een DNA-onderzoekslaboratorium om DNA-profielen op te stellen en onderling te vergelijken (art. 44quater, 44quinquies en goundecies Sv.), de medewerking van een operator van een elektronisch communicatienetwerk of van een verstrekker van een elektronische communicatiedienst bij onderzoeksmaatregelen inzake telefonie en andere communicatie (art. 46bis, 88bis en 9oquater Sv.), de medewerking van een postoperator bij het onderscheppen van briefwisseling (art.

I79 Aanvankelijk was de inkijkoperatie ook mogelijk in het kader van het zogenaamde mini-onderzoek, waarbij de procureur des Konings de onderzoeksrechter kan vorderen om één welbepaalde dwangmaatregel te verrichten, waarna deze het dossier terugstuurt aan de procureur des Konings die dan het opsporingsonderzoek kan verderzetten (artikel 28 septies Sv.; merk op dat de onderzoeksrechter in dat geval ook kan beslissen zelf het onderzoek verder te zetten, in welk geval het verder onderzoek dus een gerechtelijk onderzoek wordt ...). De mogelijkheid van een inkijkoperatie in het kader van het mini-onderzoek werd evenwel vernietigd door het Arbitragehof in het reeds geciteerde arrest nr. 202/2004 van 2I december 2004, daar de inkijkoperatie een vergelijkbare inbreuk op het grondrecht van de onschendbaarheid van de woning uitmaakt als de huiszoeking, die van de toepassing van het mini-onderzoek is uitgesloten.

I80 Zie voor een uitvoerige bespreking van deze verschillen B. VAN GEEBERGEN, 'Inkijkoperatie', in Strafrecht en Strafuordering. Commentaar met overzicht van rechtspraak en rechtsleer, Mechelen, WoltersKluwer, losbl., I4 e.v., nr. 23 e.v. 
46 ter Sv.) of nog de medewerking van banken of kredietinstellingen bij het verzamelen van bancaire informatie (art. 46quater Sv.).

In vele van deze gevallen is de weigering om medewerking te verlenen overigens strafbaar met geldboeten ${ }^{181}$ en soms zelfs met gevangenisstraffen. ${ }^{182}$

Het gaat in deze gevallen evenwel overduidelijk om het vorderen van de medewerking van een derde, die niet bij de te onderzoeken feiten betrokken is. Dergelijke medewerkingsverplichtingen dienen derhalve niet vanuit het gezichtspunt van de rechten van verdediging te worden bekeken.

5I. In de bijzondere wetgeving - eens te meer vaak in het kader van het economisch en financieel recht of van het sociaal recht (zie hierboven, nr. 48) - wordt meermaals de verplichting ingevoerd om documenten aan de speurders over te leggen.

Typevoorbeeld is ook hier artikel XV.3 van het Wetboek van Economisch Recht. Luidens die bepaling kunnen de door de bevoegde minister aangeduide ambtenaren met het oog op het opsporen en vaststellen van inbreuken op het Wetboek en zijn uitvoeringsbesluiten, zich op eerste vordering (zowel zonder zich te verplaatsen als na zich naar de plaatsen te hebben begeven) alle inlichtingen, documenten, stukken, boeken, bescheiden, gegevensbestanden en geïnformatiseerde dragers van gegevens laten verstrekken die zij tot het volbrengen van hun taken nodig achten (art. XV.3, $5^{\circ}$ W.E.R., dat eraan toevoegt dat zij van één en ander ook gratis afschrift mogen nemen of ze gratis mogen meenemen tegen afgifte van een ontvangstbewijs).

De weigering om de gevraagde documenten over te leggen kan bestraft worden als belemmering van toezicht overeenkomstig artikel XV.I26 W.E.R. Luidens die bepaling wordt de vrijwillige verhindering of belemmering tot het uitoefenen van de functies van de door de bevoegde minister aangeduide ambtenaren of de politieambtenaren van de lokale en federale politie bestraft met een sanctie van niveau 4 (dit is een geldboete van 26 tot 50.000 euro $^{183}$ ) en, bij herhaling binnen de vijf jaar, met een sanctie van niveau 5 (dit is een geldboete van 250 tot 100.000 euro en/of een gevangenisstraf van één maand tot één jaar ${ }^{\mathrm{r} 84}$ ).

52. De vraag of dergelijke strafrechtelijk gesanctioneerde verplichtingen tot het overleggen van documenten wel te verenigen vallen met het zwijgrecht, heeft in de Belgische doctrine al heel wat inkt doen vloeien. Het is niet mogelijk (en ook niet nodig) in het kader van dit preadvies deze discussie vanuit de positie van de

I8I De operator van een elektronisch communicatienetwerk of de verstrekker van een elektronische communicatiedienst die zijn medewerking weigert, wordt gestraft met een geldboete van 26 tot

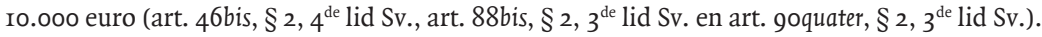

I82 De postoperator die zijn medewerking weigert, wordt gestraft met een gevangenisstraf van 8 dagen tot I jaar en/of met een geldboete van 26 tot 10.000 euro (art. 46 ter, $\$ 2,4$ de lid Sv.), de bank of kredietinstelling die zijn medewerking weigert, wordt eveneens gestraft met een gevangenisstraf van 8 dagen tot I jaar en/of met een geldboete van 26 tot ro.00o euro (art. 46 quater $\$ 3,4$ de lid Sv.).

I83 Art. XV.70, $5^{\text {de }}$ lid W.E.R.

I84 Art. XV.70, $6^{\text {de }}$ lid W.E.R. 
rechtspersoon nogmaals over te doen. Moge hier worden volstaan met volgende beschouwingen.

Vooreerst wordt vaak een onderscheid gemaakt al naar gelang de aard van de documenten. In het arrest Saunders/Verenigd Koninkrijk van 17 december 1996 heeft het Europese Hof voor de Rechten van de Mens beslist dat het zwijgrecht er niet aan in de weg staat, materiaal waarvan het bestaan onafhankelijk is van de wil van de verdachte in een strafprocedure te gebruiken. ${ }^{185}$ Daarbij kan gedacht worden aan documenten, die de wet verplicht op te maken en te bewaren.

$\mathrm{Na}$ een grondige studie van de latere rechtspraak uit Straatsburg komt A. DE NAUW tot de vaststelling dat deze te weinig coherent is om er sluitende principes uit af te kunnen leiden. Hoewel uit sommige arresten argumenten kunnen worden geput om voor te houden dat zelfs het gebruik van documenten die de betrokkene krachtens de wet moet opmaken en bewaren een inbreuk is op het recht zichzelf niet te belasten, verschaffen andere arresten dan weer steun voor de omgekeerde stelling, naar luid waarvan het gebruik van dergelijke documenten geen inbreuk vormt op het recht zichzelf niet te moeten belasten. ${ }^{\text {I8 }}$

Wellicht wordt het onderscheid, al naar gelang de documenten wel of niet bestaan onafhankelijk van de wil van de verdachte, zelfs gaandeweg verlaten ${ }^{187}$ maar dient eerder gekeken te worden naar een drietal criteria om te beoordelen of artikel 6 van het EVRM werd geschonden: de aard en de ernst van de dwang die gebruikt werd om het bewijs te verkrijgen, het bestaan van relevante procedurele waarborgen en het gebruik dat van de aldus verkregen informatie vooropgesteld was. ${ }^{188}$

Voorts werd in de hierboven reeds geciteerde Citibank-zaak (zie nr. 35) een erg belangwekkende en nog veel verder gaande inperking aangebracht in de draagwijdte van wetsbepalingen, die verplichten tot het overleggen van documenten.

Aanleiding was het oude artikel I04, $2^{\circ}$ van de vroegere wet van I4 juli I99I op de handelspraktijken en de voorlichting en bescherming van de consument, waarin het met opzet verhinderen of belemmeren van het vervullen van de opdracht van de door de minister aangeduide ambtenaren tot opsporing en vaststelling van inbreuken strafbaar werd gesteld. Dit artikel is m.a.w. een voorloper van het huidige artikel XV.3, $5^{\circ}$ W.E.R. (zie hierboven, nr. 5I). Aan de Citibank werd meermaals de overlegging van documenten gevraagd - tweemaal door de Algemene Directie Controle en Bemiddeling van de Federale Overheidsdienst Economie en eenmaal door het openbaar ministerie - onder bedreiging van de toepassing van de

I85 EHRM, arrest Saunders/Verenigd Koninkrijk d.d. 17 december 1996, Rep. Eur. Court H.R. 1996, VI, 2044, i.h.b. $\$ 69$.

I86 A. DE NAUW, 'Het zwijgrecht in het strafrecht van het bedrijfsleven', in De Praktijkjurist XVI, Gent, Story, $2010,267$.

I87 C. SAVONET, 'Le droit au silence: un droit relatif?', Rev.Trim.Dr.H. 2009, 763 e.v.

I88 R. VERSTRAETEN en Ph. TRAEST, 'Het recht van verdediging in de onderzoeksfase', NC 2008, 9899, nr. 39; zie hierover kritisch M.-A. BEERNAERT, H.D. BOSLY en D. VANDERMEERSCH, Droit de la procédure pénale, Brugge, la Charte, 2014, 33-34. 
strafrechtelijke sancties in het voormelde artikel Io4, $2^{\circ}$ van de Handelspraktijkenwet. De bank had daarop de gevraagde documenten overgelegd.

Het Brusselse hof van beroep heeft deze stukken, alsook de onderzoeksverrichtingen en vaststellingen die op grond daarvan zijn gebeurd en die daaruit dus voortvloeien, uit de debatten geweerd (behoudens de stukken à décharge), daar zij met miskenning van het zwijgrecht waren verkregen. ${ }^{189}$

De Procureur-generaal bij het hof van beroep te Brussel tekende cassatieberoep aan, daar het bestreden arrest door het weren van de stukken op onrechtmatige wijze het toepassingsgebied van artikel $104,2^{\circ}$ van de Handelspraktijkenwet zou hebben beperkt. Dit middel werd door het Hof van Cassatie verworpen in niet mis te verstane bewoordingen:

'Het zwijgrecht, dat besloten ligt in het recht op een eerlijke behandeling van de zaak, houdt niet alleen het recht in om niet tegen zichzelf te getuigen maar ook het recht van iedere inverdenkinggestelde om niet mee te werken aan zijn eigen beschuldiging. Aangezien de verdachte niet kan worden gedwongen om mee te werken aan het bewijs van de gegrondheid van de beschuldiging die tegen hem zal worden ingebracht, kan hij niet gestraft worden voor het niet-meedelen van gegevens die hem zullen ontmaskeren.

Daaruit volgt dat de rechter die uitspraak moet doen over een strafuervolging, het bewijs moet weren dat ontleend is aan gegevens die van de verdachte onder bedreiging van een sanctie zijn verkregen.' ${ }^{190}$

Dit arrest heeft dus tot gevolg dat het voorleggen van stukken, documenten en dgl. niet onder bedreiging van sancties kan worden gevorderd (noch in de fase van het administratief onderzoek, noch in de fase van het daaropvolgend strafrechtelijk onderzoek $^{19 I}$ ) van diegene die ervan verdacht wordt een inbreuk te hebben gepleegd.

Uiteraard kan de verdachte rechtspersoon, tot wie dergelijke vordering wordt gericht, steeds vrijelijk beslissen daar toch op in te gaan (wat in de praktijk overigens vaak gebeurt). Het lijkt dan ook aannemelijk dat de houding van de rechtspersoon t.a.v. een dergelijke vordering enkel bepaald kan worden via de gebruikelijke beslissingskanalen en -methoden van de vennootschap in kwestie.

53. Tot slot wordt nog even kort stilgestaan bij artikel 88quater Sv. ${ }^{192}$ dat een tweetal medewerkingsverplichtingen in het leven roept m.b.t. de zoeking in een informaticasysteem.

Overeenkomstig de eerste paragraaf van deze bepaling kan de onderzoeksrechter personen, van wie hij vermoedt dat ze een bijzondere kennis hebben van het informatica-

I89 Brussel 2I mei 20I2, Dr.pén.entr. 20I2, I43.

I90 Cass. I9 juni 20I3, AR P.I2.II50.F, Dr.pén.entr. 20I4, I57 e.v. concl. AG VANDERMEERSCH en noot L. HUYBRECHTS.

IgI L. HUYBRECHTS, 'Les arrêts de la Cour européenne des droits de l'homme Chambaz contre Suisse et Saint-Paul Luxembourg S.A. contre Luxembourg: peaux de chagrin à l'investigation fiscale et de la visite domiciliaire?' (noot onder Cass., I9 juni 2013), Dr.pén.entr. 2014, I67, nr. 3.

I92 Ingevoerd door de wet van 28 november 2000 inzake informaticacriminaliteit, BS 3 februari $200 \mathrm{I}$. Zie desbetreffend J. KEUSTERMANS, F. MOLS en T. DE MAERE, 'Informaticacriminaliteit', in Strafrecht en Strafvordering. Commentaar met overzicht van rechtspraak en rechtsleer, Mechelen, WoltersKluwer, losbl., 35-26, nr. 77-80. 
systeem dat het voorwerp uitmaakt van de zoeking of van diensten om gegevens die worden opgeslagen, verwerkt of overgedragen door middel van een informaticasysteem, te beveiligen of te versleutelen, bevelen inlichtingen te verstrekken over de werking ervan en over de wijze om er toegang toe te verkrijgen, of in een verstaanbare vorm toegang te verkrijgen tot de gegevens die door middel daarvan worden opgeslagen, verwerkt of overgedragen. Hierbij dacht de wetgever o.m. aan de toegangsmogelijkheden tot het systeem, de configuratie, de beveiliging en de crypto-grafische sleutels. ${ }^{193}$

Een gelijkaardige medewerkingsverplichting werd opgenomen in het kader van het afluisteren van telefoongesprekken of het onderscheppen van telecommunicatie (art. goquater, $§ 4$, I $^{\text {ste }}$ lid Sv.).

De tweede paragraaf vervolgt dat de onderzoeksrechter tevens iedere geschikte persoon kan bevelen om zelf het informaticasysteem te bedienen of de ter zake dienende gegevens, die door middel daarvan worden opgeslagen, verwerkt of overgedragen, naargelang van het geval te zoeken, toegankelijk te maken, te kopiëren, ontoegankelijk te maken of te verwijderen ${ }^{194}$ in de door hem gevorderde vorm. De wetgever dacht hierbij o.m. aan het doen functioneren van de computer of het opvragen van bepaalde bestanden. ${ }^{195}$

Ook hier werd een gelijkaardige medewerkingsverplichting opgenomen in het kader van het afluisteren van telefoongesprekken of het onderscheppen van telecommunicatie (art. 9oquater, $\S 4,2^{\text {de }}$ lid Sv.).

De weigering medewerking te verlenen of het hinderen van de zoeking in het informaticasysteem wordt gestraft met gevangenisstraf van zes maanden tot één jaar en/ of een geldboete van 26 tot 20.000 euro (art. 88quater, $\$ 3$ Sv.; tevens art. 9oquater, $\S 4,3^{\text {de }}$ lid Sv.).

54. Wat het bevel aan een geschikte persoon betreft om het informaticasysteem te bedienen en de gegevens toegankelijk te maken, wordt uitdrukkelijk gepreciseerd dat het niet kan worden gegeven aan de verdachte, noch aan de personen bedoeld in artikel ${ }_{15} 6 \mathrm{~Sv} .{ }^{196}$ (art. 88quater, $\S 2$, $2^{\text {de }}$ lid Sv. ${ }^{197}$ ). De wetgever heeft zulks bepaald teneinde het zwijgrecht van de verdachte te respecteren. ${ }^{198}$

I93 Memorie van toelichting bij het wetsontwerp, Parl. St., Kamer, I999-2000, nr. 0213/00I en 02I4/oor, p. 27 .

I94 In deze laatste drie gevallen gaat het om de uitvoeringswijzen van een zgn. databeslag, dat kan gebeuren via het kopiëren van gegevens, het ontoegankelijk maken van gegevens om hun integriteit te bewaren en het verwijderen van gegevens die strijdig zijn met de openbare orde of de goede zeden (art. 39bis Sv.).

I95 Verslag namens de Kamercommissie voor Justitie, Parl. St., Kamer, I999-2000, nr. 02I3/004, p. Io.

I96 Het gaat om de bloedverwanten van de beklaagde in opgaande of nederdalende lijn, zijn broers en zusters of aanverwanten in dezelfde graad, alsook de echtgenoot of echtgenote, zelfs nadat de echtscheiding is uitgesproken: deze personen worden niet opgeroepen of toegelaten om te getuigen, tenzij het openbaar ministerie, de burgerlijke partij noch de beklaagde zich ertegen verzet hebben dat zij gehoord worden (art. $156 \mathrm{~Sv}$.).

I97 Eigenaardig genoeg ontbreekt deze precisering voor de gelijkaardige medewerkingsverplichting, omschreven in artikel goquater, $\S 4,2^{\text {de }}$ lid Sv.

I98 Memorie van toelichting bij hetwetsontwerp, Parl. St., Kamer, I999-2000, nr. 02I3/00I en 02I4/oor, p. 27. 
Het is opmerkelijk dat deze precisering niet herhaald wordt voor het bevel aan personen van wie vermoed wordt dat ze een bijzondere kennis hebben van het informaticasysteem, om inlichtingen te verstrekken over de werking ervan en over de wijze om er toegang toe te verkrijgen. Hoewel uit de parlementaire voorbereiding kan worden afgeleid dat de wetgever m.b.t. de kring van personen, die door artikel 88quater Sv. geviseerd worden, vooral dacht aan derden - 'importeurs/verdelers van computers of software, trusted third parties, dienstenverstrekkers, operatoren, bedrijfsingenieurs die een specifieke informaticaconfiguratie hebben uitgewerkt, beveiligingsspecialisten ...' ${ }^{199}$ - is de omschrijving, ook in de eerste paragraaf van deze bepaling, ruim genoeg om ook de verdachte natuurlijke personen of personen die werkzaam zijn voor de verdachte rechtspersoon te kunnen omvatten.

Het is niet zeker of dit een weloverwogen keuze van de wetgever is geweest. Aan de ene kant was de wetgever van oordeel dat deze verplichtingen tot medewerking - dus andere dan de verplichting om het informaticasysteem daadwerkelijk te bedienen - niet onverenigbaar zijn met het EVRM, waarbij hij zich om eerder onduidelijke redenen beriep op het arrest Saunders/Verenigd Koninkrijk van I7 december 1996. ${ }^{200}$ Aan de andere kant evenwel werd gepreciseerd dat, aangezien het onmogelijk is om de werking van alle systemen te kennen, de opsporingsdiensten vaak verplicht zijn om de medewerking te vragen van de systeembeheerder zelf, maar dat deze medewerking niet kan worden opgelegd: indien de systeembeheerder niet wenst mee te werken, moet er een externe deskundige worden aangesteld. ${ }^{201}$

M.i. komt het hoe dan ook nogal artificieel over, desbetreffend een onderscheid te maken tussen enerzijds het geven van informatie over de werking van een informaticasysteem en over de wijze van toegang ertoe en anderzijds het daadwerkelijk zelf bedienen van het informaticasysteem om de erin opgeslagen informatie toegankelijk te maken: beide bevelen lijken moeilijk tot de verdachte natuurlijke persoon of rechtspersoon te kunnen worden gericht.

55. De Commissie voor de bescherming van de persoonlijke levenssfeer ${ }^{202}$ heeft uit eigen beweging op I3 december 1999 een advies uitgebracht over het wetsontwerp inzake informaticacriminaliteit. In dat advies heeft de Commissie m.b.t. de bepaling van artikel 88quater, $§ ~ 2,2^{\text {de }}$ lid Sv. - dus het verbod aan de verdachte het bevel te geven om het informaticasysteem te bedienen en de gegevens toegankelijk te maken - de vraag geopperd wat de gevolgen zullen zijn indien de verdachte een rechtspersoon is: wordt ook een orgaan of een aangestelde beschermd door de regel dat men zichzelf niet moet incrimineren? ${ }^{203}$ De Commissie heeft deze vraag evenwel niet beantwoord.

I99 Nogmaals memorie van toelichting bij het wetsontwerp, Parl. St., Kamer, I999-2000, nr. 02I3/OoI en $0214 / 001$, p. 27.

200 Memorie van toelichting bij het wetsontwerp, Parl. St., Kamer, I999-2000, nr. 0213/00I en 02I4/00I, p. 27-28.

201 Verslag namens de Kamercommissie voor Justitie, Parl. St., Kamer, I990-2000, nr. 0213/004, p. 42.

202 Het gaat om een commissie die bij de Kamer van volksvertegenwoordigers is ingesteld en samengesteld is uit leden die worden aangewezen door de Kamer (art. 23 van de wet van 28 november 2000 inzake informaticacriminaliteit, BS 3 februari 2001).

203 Advies nr. 33 van I3 december 1999, opgenomen als bijlage II bij het verslag namens de Kamercommissie voor Justitie, Parl. St., Kamer, 1999-2000, nr. 0213/004, p. 9I-92. 
Het lijkt mij, in het licht van het hoger beschreven standpunt m.b.t. de uitoefening van het zwijgrecht van de rechtspersoon, dat deze vraag onvoldoende scherp gesteld is. Het gaat er niet om te weten of de organen of aangestelden zelf beschermd worden door de regel dat men niet verplicht kan worden zichzelf te incrimineren, het gaat er integendeel om te weten of zij het recht van de rechtspersoon, zichzelf niet te moeten incrimineren, kunnen uitoefenen. Om alle hierboven vermelde redenen meen ik dat zulks inderdaad het geval is.

\section{Conclusie}

56. Meer dan 5 jaar na de invoering ervan, blijkt de strafrechtelijke verantwoordelijkheid van rechtspersonen de praktijk nog steeds voor belangrijke uitdagingen te plaatsen.

Op materieelrechtelijk vlak vereist deze nieuwe vorm van strafrechtelijke verantwoordelijkheid immers een hernieuwde conceptualisering van de begrippen daderschap (wanneer kan een strafbare gedraging geachtworden door een rechtspersoon te zijn gepleegd?) en schuld (waaruit kan men de door de strafwet vereiste schuldvorm - opzet of onachtzaamheid - afleiden in hoofde van een rechtspersoon?). Het is twijfelachtig of deze nieuwe concepten reeds voldoende zijn uitgekristalliseerd.

Doch ook op formeelrechtelijk vlak moeten bepaalde tot voor kort evident geachte principes worden herdacht. De hierboven beschreven kwesties van de vertegenwoordiging en de verschijning van de rechtspersoon en van de uitoefening van de rechten van verdediging - in het bijzonder het zwijgrecht - van de rechtspersoon tonen zulks bij uitstek aan.

Daarbij valt mij telkens op met hoeveel valse vragen het denken over de rechtspersoon als mogelijke strafbare dader wordt omgeven. Die valse vragen ${ }^{204}$ vertroebelen de dogmatische theorievorming en daardoor de praktische uitwerking van de strafrechtelijke verantwoordelijkheid van rechtspersonen.

Moge dit preadvies een kleine bijdrage leveren tot het opklaren van de benevelde geesten en het opruimen van de intellectuele blokkades (zie hierboven, nr. I), die de groei naar volwassenheid van het autonome stelsel van strafrechtelijke verantwoordelijkheid van rechtspersonen in België belemmeren.

204 Bv. door wie dient de materiële gedraging gesteld te worden opdat de rechtspersoon er strafrechtelijk verantwoordelijk voor zou zijn (zie hierboven, nr. 3), kan een eenmans-bvba zich verzetten tegen het plegen van misdrijven, via haar structuur, door de enige zaakvoerder en aandeelhouder (zie hierboven, nr. 3I), heeft de lasthebber ad hoc een zwijgrecht (hierboven, nr. 4I). 